Document downloaded from:

http://hdl.handle.net/10251/144584

This paper must be cited as:

Hassan, A.; Martinez-Ballester, S.; Gonzálvez-Maciá, J. (10-2). Comparison of different modeling approaches for minichannel evaporators under dehumidification. Heat and Mass Transfer. 55(10):2901-2919. https://doi.org/10.1007/s00231-019-02622-0

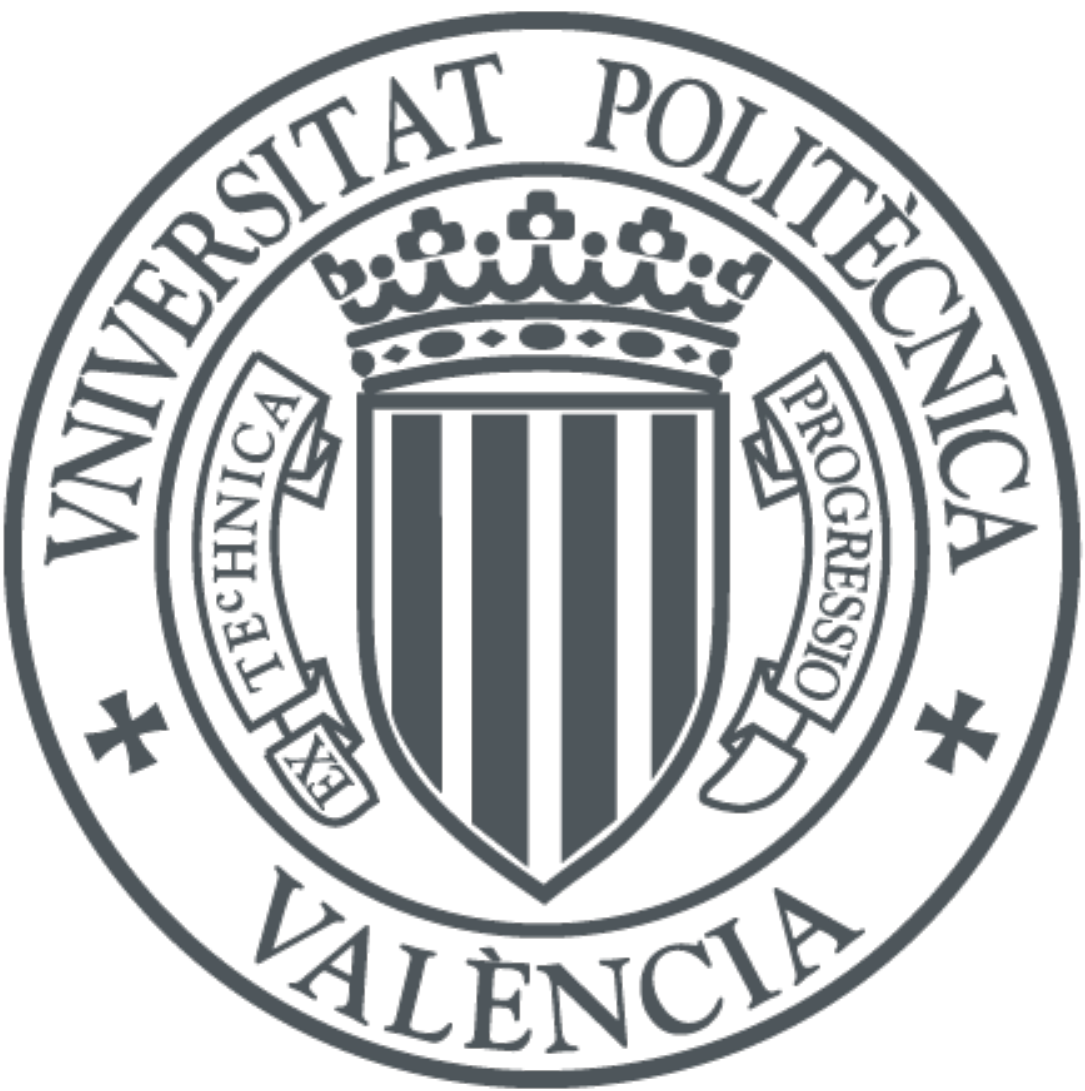

The final publication is available at

https://doi.org/10.1007/s00231-019-02622-0

Copyright Springer-Verlag

Additional Information 


\title{
Comparison of different modeling approaches for minichannel evaporators under dehumidification
}

\author{
Abdelrahman Hussein Hassan $^{1,2} \cdot$ Santiago Martínez-Ballester ${ }^{3}$ • José Gonzálvez-Maciá ${ }^{1}$ \\ Received: 1 May 2018 / Accepted: 9 April 2019 \\ (C) Springer-Verlag GmbH Germany, part of Springer Nature 2019
}

\begin{abstract}
This paper firstly presents a comprehensive minichannel evaporator model (MCHX-1D-MB) based on fin theory coupled with the moving boundary technique along fin height. To validate the presented model, experimental data for R-134a and R-744 $\left(\mathrm{CO}_{2}\right)$ minichannel evaporators were used. The proposed model successfully predicted the cooling capacity of $\mathrm{R}-134 \mathrm{a}$ and $\mathrm{CO}_{2}$ evaporators with mean absolute error values of \pm 1.8 and $\pm 4.3 \%$, respectively. Regarding the outlet air temperature, the mean absolute errors in the estimated results were \pm 0.43 and $\pm 0.9{ }^{\circ} \mathrm{C}$ for $\mathrm{R}-134 \mathrm{a}$ and $\mathrm{CO}_{2}$ evaporators, respectively. Finally, to evaluate the impact of widely used assumption of cut fin on the air-side performance of minichannel evaporators, another model was developed (MCHX-1D-CF). The comparative study revealed that the most remarkable deviations between the two models appear when the evaporator operates under partially wet conditions, which were up to $\approx 12 \%$ in the latent heat transfer rate.
\end{abstract}

\section{Nomenclature}

A Contact surface area $\left(\mathrm{m}^{2}\right)$

Ac Cross-section area $\left(\mathrm{m}^{2}\right)$

$b \quad$ Slope of saturation curve defined in Table $1(1 / \mathrm{K})$

$C_{p, m a} \quad$ Specific heat for moist air $(\mathrm{J} / \mathrm{kg} \cdot \mathrm{K})$

$D_{h} \quad$ Hydraulic diameter (m)

$f \quad$ Friction coefficient (-)

G Mass flux $(\mathrm{kg} / \mathrm{m} \cdot \mathrm{s})$

$g \quad$ Gravitational acceleration $(\mathrm{m} / \mathrm{s})$

$H_{f} \quad$ Fin height (m)

$h_{f g} \quad$ Latent heat of water condensation $(\mathrm{J} / \mathrm{kg})$

$k \quad$ Thermal conductivity $(\mathrm{W} / \mathrm{m} \cdot \mathrm{K})$

$l \quad$ Distance between two wall cells (m)

Le $\quad$ LEWIS number $(-)$

$m \quad$ Dry fin parameter defined in Eq. $2(\mathrm{~m})$

$M \quad$ Wet fin parameter defined in Eq. 2 (m)

$\dot{m} \quad$ Mass flow rate $(\mathrm{kg} / \mathrm{s})$

$n \quad$ Number of cells (-)

Abdelrahman Hussein Hassan abhusab1@upvnet.upv.es

1 Instituto Universitario de Investigación en Ingeniería Energética, Universitat Politècnica de València, Camino de Vera s/n, 46022 Valencia, Spain

2 Mechanical Power Engineering Department, Faculty of Engineering, Zagazig University, Zagazig 44519, Egypt

3 Thermo King (Global Marine Solutions), C/Sant Josep 140-142, 08980 Sant Feliu de Llobregat, Spain
N Numerical grid dimension (-)

NMTU Number of mass transfer units defined in Eq. $16(-) \quad 58$

NTU Number of transfer units defined in Eq. $15(-)$

$P \quad$ Perimeter (m)

$p \quad$ Pressure $(\mathrm{Pa})$

$Q \quad$ Heat transfer rate $(\mathrm{W})$

$Q_{c} \quad$ Cooling capacity $(\mathrm{kW})$

$\mathrm{RH} \quad$ Relative humidity $(-)$

$T \quad$ Temperature $\left({ }^{\circ} \mathrm{C}\right)$

$T^{*} \quad$ Modified temperature for moist air defined in Table $1\left({ }^{\circ} \mathrm{C}\right)$

$U_{r} \quad$ Overall heat transfer coefficient for refrigerant-side $\left(\mathrm{W} / \mathrm{m}^{2} \cdot \mathrm{K}\right)$

$U_{\text {wet,a }}$ Overall heat transfer coefficient for air-side under wet conditions $\left(\mathrm{W} / \mathrm{m}^{2} \cdot \mathrm{K}\right)$

$V \quad$ Volume $\left(\mathrm{m}^{3}\right)$

$W \quad$ Humidity ratio $\left(\mathrm{kg}_{\mathrm{w}} / \mathrm{kg}_{\mathrm{da}}\right)$

$x, y, z \quad$ Spatial coordinates (m)

$X \quad$ Refrigerant quality (-)

\section{Greek symbols}

$\alpha \quad$ Sensible heat transfer coefficient $\left(\mathrm{W} / \mathrm{m}^{2} \cdot \mathrm{K}\right)$

$\alpha_{\text {wet,a }}$ Total heat transfer coefficient for air-side under wet 96 conditions defined in Table $1\left(\mathrm{~W} / \mathrm{m}^{2} \cdot \mathrm{K}\right)$

$\beta \quad$ Parameter defined in Table $1(\mathrm{~K})$

$\Omega \quad$ Void fraction (-)

$\zeta_{1} \quad$ Parameter defined in Eq. $17(\mathrm{~m})$

$\zeta_{2} \quad$ Parameter defined in Eq. $18(\mathrm{~m})$

$\theta \quad$ Temperature difference $(\mathrm{K})$

$\lambda$ Thermal conductance $(\mathrm{W} / \mathrm{K})$ 


$\begin{array}{lll}110 & \xi & \text { Tube orientation (deg) } \\ 113 & \rho & \text { Density }\left(\mathrm{kg} / \mathrm{m}^{3}\right) \\ 118 & \Phi_{L}^{2} & \text { Two-phase multiplier }(-) \\ 116 & \psi & \text { Parameter defined in Eq. } 2(\mathrm{~K}) \\ 118 & \omega & \text { Humidity ratio difference }\left(\mathrm{kg}_{\mathrm{w}} / \mathrm{kg}_{\mathrm{da}}\right) \\ 120 & \text { Subscripts } & \\ 123 & a & \text { Air or air cell index } \\ 128 & \text { acc } & \text { Acceleration } \\ 126 & c & \text { Centroid of tube wall cell } \\ 128 & \text { cond } & \text { Conduction } \\ 130 & \text { cont } & \text { Contraction } \\ 133 & d p & \text { Dew point } \\ 138 & \text { exp } & \text { Expansion } \\ 136 & f & \text { Fin or fin cell index } \\ 138 & f B & \text { Fin base } \\ 140 & \text { fp } & \text { Fin portion index } \\ 143 & \text { fric } & \text { Friction } \\ 148 & f T & \text { Fin tip } \\ 146 & G & \text { Gas } \\ 148 & \text { grav } & \text { Gravitational } \\ 150 & \text { in } & \text { Inlet } \\ 153 & k & \text { Direction index } \\ 158 & L & \text { Liquid } \\ 156 & \text { lat } & \text { Latent } \\ 158 & \text { out } & \text { Outlet } \\ 160 & r & \text { Refrigerant or refrigerant cell index } \\ 163 & s & \text { Surface of tube wall cell } \\ 167 & \text { sat } & \text { Saturated } \\ 166 & \text { seg } & \text { Tube segment } \\ 168 & \text { sens } & \text { Sensible } \\ 170 & s p & \text { Superheat region } \\ 173 & t & \text { Tube or tube wall cell index } \\ 178 & \text { tot } & \text { Total } \\ 176 & t p & \text { Two-phase region } \\ 178 & w & \text { Water } \\ 18 \emptyset & \text { W, E, S, N } & \text { Directions of neighbor tube wall cell }\end{array}$

\section{Introduction}

Heat exchangers are key components in refrigeration and airconditioning systems. They play an important role on the energy efficiency, refrigerant charge, and physical size of such systems. Compared to conventional heat exchangers, the minichannel heat exchangers have many desirable features, such as higher performance and compactness, and lower refrigerant charge.

Nowadays, numerical models and software are very suitable tools for designing and testing complex minichannel heat exchangers. These tools allow us to save lots of costs and time in carrying out experimental campaigns.

When the minichannel heat exchanger is employed as an evaporator, some challenges emerge in the air-side such as the drainage of condensed water and frost formation. These challenges motivate the efforts to continue working in modeling of the simultaneous cooling and dehumidification process.

Several minichannel evaporator models are available in the literature, among them are Kim and Bullard [1], Jin et al. [2], Wu and Webb [3], Brix et al. [4], Zhao et al. [5], Ren et al. [6], Gossard et al. [7], Huang et al. [8], and Tian et al. [9].

Kim and Bullard [1] developed a minichannel evaporator model for $\mathrm{CO}_{2}$ air-conditioning system. The evaporator was divided into segments along the refrigerant flow direction for which the energy and mass balances were applied. Furthermore, they developed new correlations for air-side heat transfer and frictional losses, for both dry and wet conditions. Regarding refrigerant-side calculations, the Hwang [10] correlation for heat transfer coefficient, and Tran et al. [11] correlation for frictional pressure drop were adopted. The results showed that the root mean square errors for the cooling capacity and refrigerant-side pressure drop were \pm 2.6 and \pm $13.1 \%$, respectively. Another $\mathrm{CO}_{2}$ minichannel evaporator model, which adopted similar modeling assumptions as the model of Kim and Bullard [1], was presented by Jin et al. [2]. Moreover, the proposed model considered the pressure losses both in the headers and at the inlet of tubes. Each evaporator pass was divided into 10 equal-length segments along the refrigerant flow direction. For each segment, according to the inlet air dew point and average wall temperature (tubes and fin), the model can select different procedures (totally dry or totally wet procedure) to evaluate the total heat transfer rate. The authors compared several correlations of refrigerant-side heat transfer and pressure drop before selecting appropriate correlations for the model. For calculating the air-side heat transfer coefficient and pressure drop, the Kim and Bullard correlations $[12,13]$ were adopted. The results showed that using the Cheng et al. [14] and Jassim and Newell [15] correlations, respectively, for refrigerant-side heat transfer and pressure drop, the model developed predicted the experimental data with reasonable accuracy. The root mean square deviations for cooling capacities and refrigerant-side pressure drops were \pm 1.9 and $\pm 12.3 \%$, respectively. They also concluded that the pressure drop due to headers and inlet ports can be neglected due to the small proportion compared with the total pressure drop within the whole evaporator.

A numerical model for brazed aluminum minichannel evaporator under dehumidification was developed by $\mathrm{Wu}$ and Webb [3]. The evaporator was discretized along the refrigerant flow into three regions including the two-phase, liquid-phase, and superheat regions. In the liquid-phase and superheat regions, the refrigerant-side heat transfer and friction coefficients were evaluated using correlations proposed by Petukhov [16]. On the other hand, for the two-phase region, the heat transfer correlation of Shah [17] was used alongside the modified Friedel correlation from Zhang and Webb [18] for pressure drop losses. In this model the dry air-side heat 
transfer and pressure drop were evaluated using the semianalytical correlations of Webb et al. [19]. The model was validated with R-404A evaporator, the results showed that the cooling capacity was overpredicted by $8 \%$. The researchers reported that the main reason for this could be the flow maldistribution in the branch tubes.

On the other hand, Brix et al. [4] proposed a onedimensional model for R-134a minichannel evaporator to investigate the effects of maldistribution on the global performance. They used a finite volume approach to discretize the evaporator tubes assuming steady state conditions, fin cut at half the height, and no heat conduction between evaporator's segments. The authors adopted the correlations proposed by Zhang et al. [20] and Müller-Steinhagen and Heck [21] to calculate, respectively, the refrigerant-side heat transfer and pressure drop. In the air-side, they used the heat transfer and pressure drop correlations developed by Kim and Bullard [12]. The authors considered two parallel tubes to evaluated the maldistribution for two different scenarios, In the first one maldistribution of the inlet quality into the tubes was considered, and in the second case a non-uniform airflow was considered. The results showed that the total cooling capacity was significantly reduced by $23 \%$, which was considered to be the upper limit of the influence of maldistribution for the study.

Zhao et al. [5] presented a simulation model for R-1234yf minichannel evaporator adopting the finite element technique and effectiveness-NTU method to calculate the heat transfer rate. Each tube was divided into 20 segments in the refrigerant flow direction assuming uniform refrigerant and air flow, adiabatic-fin-tip at half the height, and no maldistribution in the headers. The researchers compared between six different correlations regarding the two-phase heat transfer for refrigerant. The refrigerant-side pressure drop was calculated using Friedel [22] correlation. On the other hand, the air-side heat transfer and frictional pressure losses were evaluated using Chang et al. [23, 24] correlations for dry surfaces, and Kim and Bullard [13] correlations for wet surfaces. The results showed that the model with Kandlikar's correlation [25] showed the best prediction of cooling capacity, with mean deviation of $5.9 \%$ compared with the experimental results. The authors indicated that the developed model using Kandlikar's correlation also presented acceptable results for the refrigerant-side pressure drops, with mean deviations up to $21.9 \%$.

Gossard et al. [7] developed and validated a finite volume, steady state evaporator model that include rectangular minichannel tubes with louvered fin. Then the model was used to compare the thermal-hydraulic performance of some experimental refrigerant mixtures. For each tube volume, the enthalpy potential (single-potential) method, shown in $\mathrm{Wu}$ and Webb [3], was adopted to calculate the overall heat transfer coefficient. The correlation proposed by Peters and Kandlikar [26] was employed to calculate the refrigerant- side heat transfer coefficient, while the correlation of Field and Hrnjak [27] was used to evaluate the pressure drop. Regarding the air-side evaluation, the correlations of Park and Jacobi $[28,29]$ were adopted to calculate the heat transfer and pressure losses for dry and wet scenarios, respectively. They reported that the proposed model predicted the overall cooling capacity and refrigerant-side pressure drop of minichannel evaporators with an average deviation between the predicted and actual data of 8.5 and $16.5 \%$, respectively.

Recently, Tian et al. [9] presented a distributed parameter numerical model with new flow boiling heat transfer correlation for parallel flow minichannel evaporators. The evaporator was divided into three parts refrigerant-, tube-, and air-side. Each control volume was treated as a simple cross-flow arrangement between refrigerant and air flow. The moisture separation coefficient, proposed by Deru [30], was used to characterize the contribution of mass transfer in the air-side total heat transfer rate. The new correlation for two-phase heat transfer was developed based on modifying superposition model. The results showed the model yielded the mean absolute errors of 1.5 and $19.8 \%$ in predicting the cooling capacity and refrigerant-side pressure drop, respectively.

Most of these models neglect the tube-to-tube heat conduction (cut fin assumption) and do not allow for partial dehumidification scenarios within the individual evaporator's segment. These assumptions result to a simplified solution which omits the effects of previous phenomena on the evaporator performance. To the best of our knowledge, Ren et al. [6] and Huang et al. [8] presented the only two models that account for the tube-to-tube heat conduction through the fin height in minichannel evaporators.

Ren et al. [6] developed a general three-dimensional simulation approach for minichannel/microchannel heat exchangers considering the factors of heat conduction via fins, quality distribution among tubes, and flexible flow circuit arrangements. In this approach the heat exchanger was divided into port-fin control volumes, each one comprised of refrigerant cell, port (tube wall) cell, and fin-air cell. To solve the energy equation of fin-air cell, the researchers adopted the one-dimensional fin theory, assuming the conduction boundary for the fins allocated in the middle of heat exchanger to account for heat conduction between adjacent tubes. The proposed model did not account for air-side mass transfer (dehumidification) in evaporators. The model was successfully validated with the experimental data of Tuo and Hrnjak [31] to evaluate the prediction of surface temperature profile for a fully dry R-134a minichannel evaporator. The heat transfer and pressure drop of refrigerant-side were evaluated by the correlations of Gongor and Wintrton [32] and $\mathrm{Hu}$ et al. [33], respectively. The air-side heat transfer was evaluated using Chang and Wang [23] correlation.

The numerical model of Huang et al. [8], besides its capability to evaluate the heat conduction through the fin, it 
considered the partial dehumidification scenarios for minichannel evaporators. The proposed model applied a segment-by-segment approach to analyze the refrigerantand the air-side. As the model of Ren et al. [6], the authors employed the one-dimensional fin theory to simplify the energy balance for fin-air cell. However, the main difference between the two models that the model of Huang et al. [8] had also the capability to evaluate any dehumidification scenario for the fin (totally dry, partially wet, or totally wet fin) based on the fin boundary conditions (prescribed fin base and tip temperatures or adiabatic-fin-tip at half the height). In the case of wet scenarios, the dual-potential approach proposed by McQuiston [34] was used to relate the air-to-surface temperature difference and humidity ratio difference. The model was validated against computational fluid dynamics (CFD) model, proposed by the same authors, and experimental data using R-410A and R32. Regarding the refrigerant-side heat transfer and pressure drop calculations the authors adopted, respectively, the correlations of Kandlikar and Steinke [25] and Friedel [22]. The results indicated that the model had an average absolute cooling capacity deviation of $2.92 \%$ compared with experimental data. They also concluded that the fin cut assumption significantly affects the air-side cooling capacity when the wall temperature variation between adjacent tubes becomes significant, especially in the region between two refrigerant flow passes.

The previous detailed review and discussion motivated Hassan et al. $[35,36]$ to develop a comprehensive twodimensional numerical model (Fin2D-W) for wet fins of minichannel evaporators. They conducted a comparative study between the Fin 2D-W model and classical effectiveness-number of transfer units ( $\varepsilon$-NTU) approach to evaluate the air-side performance of minichannel evaporators under different dehumidifying conditions and values of superheat. The results showed that the deviations on the total heat transfer rate were up to $52 \%$. The main sources of these deviations were the implicit assumptions adopted by $\varepsilon$-NTU approach, such as the cut fin, uniform air temperature and humidity ratio along the fin height, and impossibility of considering partial dehumidification scenarios. The main conclusion of their study was that it is very important to identify firstly the actual dehumidifying conditions for the fin and tube in order to estimate correctly the latent heat transfer rate, subsequently estimating properly the total heat transfer rate.

Based on the results and recommendations of the Fin2D-W model, Hassan et al. [37] developed a more simplified model (Fin1D-MB). This model is able to retain the most important heat and mass transfer phenomena as the Fin2D-W model does, but with a much lower computational cost. Fin1D-MB model saved computational cost by up to $95 \%$, compared to the Fin2D-W model. Additionally, it successfully predicted the actual dehumidifying condition of the fin, as a consequence of adopting a moving boundary technique between the wet and dry portions along the fin height.

In the first part of this paper, a development of complete minichannel evaporator model (MCHX-1D-MB) is presented. In order to evaluate the global performance (air- and refrigerant-side) of minichannel evaporators the Fin 1D-MB air-side module [37] has been integrated into the IMST-ART simulation tool [38]. This tool has been developed by the Institute for Energy Engineering to evaluate complete refrigeration cycles or individual system components. The second part comprises a validation of the MCHX-1D-MB model against experimental data for different minichannel evaporator geometries, refrigerants, and operating conditions. Several refrigerant-side frictional pressure drop and heat transfer coefficients correlations were applied to find the ones which properly predict the experimental results. The final part of the current paper presents another model (MCHX-1D-CF) and a comparative study between the presented models to evaluate the effect of fin cutting on the air-side heat transfer rates for minichannel evaporators.

\section{Model development}

\subsection{Minichannel heat exchanger discretization}

Figure 1 presents an example of a minichannel heat exchanger that can be simulated by the IMST-ART program. This program can simulate any refrigerant circuitry arrangement: any number of refrigerant inlets and outlets; and any connection between different tube outlets/inlets at any location. Figure $2 \mathrm{a}$ shows the discretization of an evaporator into segments, where the dashed lines correspond to the thermal connections between wall cells, whereas the thicker lines correspond to the refrigerant flow path.

First, the heat exchanger is discretized along the $x$-direction (refrigerant flow), resulting into $\mathrm{N}_{\text {seg }}$ segments per tube. Each segment (Fig. 2b) consists of: a refrigerant flow that is divided into $\mathrm{N}_{\mathrm{r}, \mathrm{z}}$ channels in the $z$-direction; a flat tube which is discretized into $\mathrm{N}_{\mathrm{t}, \mathrm{z}}$ cells in the $z$-direction; air flow and fins which are always discretized into the same number of cells in

Fig. 1 Example of a minichannel heat exchanger that can be simulated by the IMST-ART program 


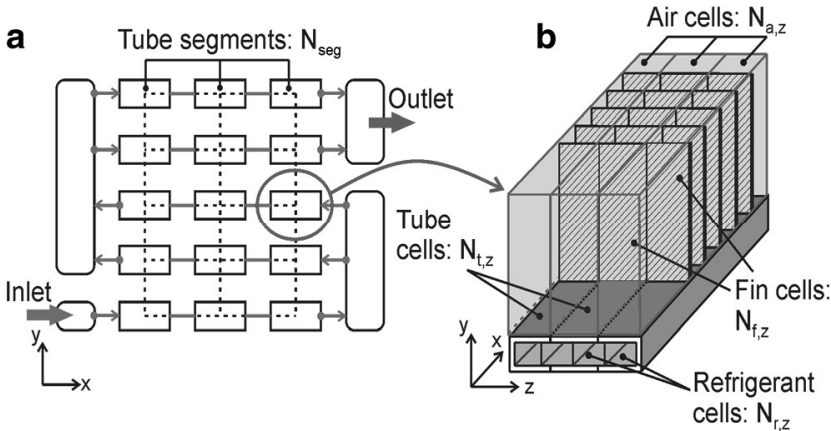

Fig. 2 a Discretization of minichannel heat exchanger to segments. b Schematic of segment discretization into cells

the $z$-direction, so that $\mathrm{N}_{\mathrm{a}, \mathrm{z}}=\mathrm{N}_{\mathrm{f}, \mathrm{z}}$. Accordingly, the discretization for a minichannel heat exchanger is summarized in the following as a grid: $\left\{\mathrm{N}_{\mathrm{seg}}, \mathrm{N}_{\mathrm{r}, \mathrm{Z}}, \mathrm{N}_{\mathrm{t}, \mathrm{z}}, \mathrm{N}_{\mathrm{a}, \mathrm{z}}\right\}$.

In the case of minichannel evaporators, the moist air exchange sensible and/or latent heat by convection with the tube and fin cells in contact. The fin cells, in turn, conduct the heat along the y-direction, and the bottom and top fin cells also conduct heat to the neighboring tube wall. Then, the tube cells transfer the total heat to the refrigerant cells in contact by convection, and to their neighboring tube cells on the plane $x-z$ by conduction. The refrigerant flows in the channels along the $x$-direction without any mixing between the channels.

Regarding the fluid cells, either air or refrigerant, there are two classifications: elemental cell and mixture cell. The elemental cell corresponds to the one described above, where the heat is exchanged with the surrounding tube and/or fin walls. The mixture cell is assumed to be adiabatic, and its function is collecting the fluid from a number of tubes and distributing it into the next tubes according to the heat exchanger circuitry. The inlet and outlet ports of each tube are connected to the corresponding mixture cells. The distribution of these mixture fluid cells and the definition of the tubes connected to them determine the flow path of each fluid.

\subsection{Governing equations}

Every fluid cell (either refrigerant or air) has two nodes, which correspond to the inlet and outlet sections in the fluid flow direction. The tube wall cells have only one node located in the centroid of the cell, as shown in Fig. 3. On the other hand, the fins do not have any nodes because a continuous function governs in this case.

\subsubsection{Tube wall analysis}

The energy conservation equation within any of the tube wall cells $t$, in contact with $n_{r}$ refrigerant cells, $n_{a}$ air cells, and $n_{f}$ fin cells can be written as:
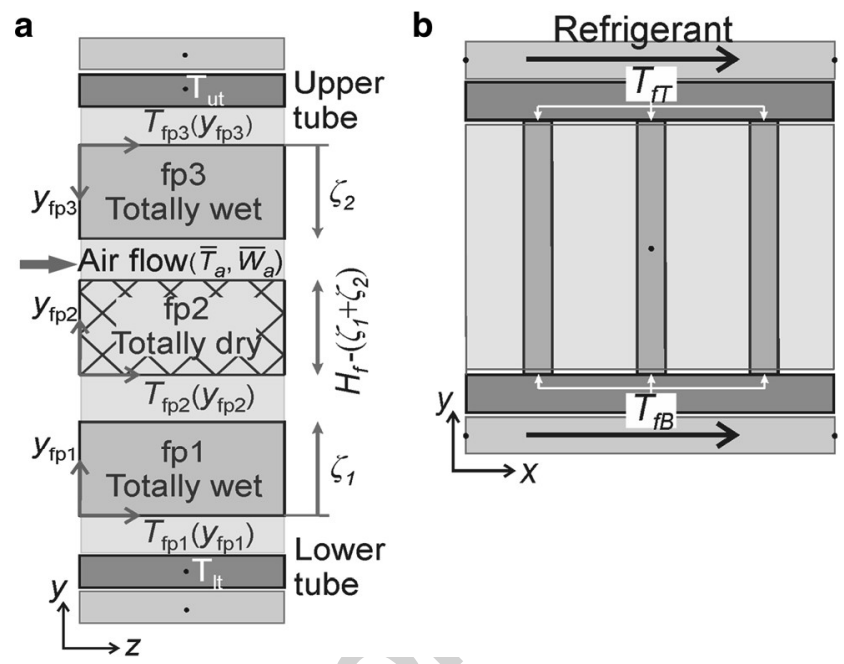

Fig. 3 a $y-z$ plane, which shows the virtual discretization of the fin in $y$ direction and boundaries between wet and dry portions, $\zeta_{1}$ and $\zeta_{2}$. b $y$-x plane, which shows the location of $T_{f B}$ and $T_{f T}$

$$
\begin{aligned}
& \nabla\left(k_{t} \cdot \nabla T_{c, t}\right) d V+\sum_{r=1}^{n_{r}} U_{r, t}\left(T_{r}-T_{c, t}\right) d A_{r, t} \\
& +\sum_{a=1}^{n_{a}} U_{\text {wet }, a, t}\left(T_{a, t}^{*}-T_{c, t}\right) d A_{a, t}+\left.\sum_{f=1}^{n_{f}} d Q_{\text {cond }, f}\right|_{\text {fin root }}=0
\end{aligned}
$$

The first term in Eq. 1 represents the 2D heat conduction between the current tube wall cell and neighboring tube wall cells in $x-z$ plane. The second and third terms represent the total heat transfer between the current tube wall cell and adjacent refrigerant cells and air cells, respectively. While, the last term represents the total heat conducted from/to the fin cells in contact with the tube.

It should be noted that a linearization scheme is used in Eq. 1 (third term) to relate the saturated air humidity ratio to its corresponding surface tube wall temperature, using the dualpotential approach [39], where $W_{\text {sat }, s, t}=a_{a, t}+b_{a, t} T_{s, t}$. It should be noticed that $T_{s, t}$ and $T_{c, t}$ are the temperatures evaluated, respectively, at the surface and centroid of the tube wall cell. Additionally, Table 1 defines the other parameters used in Eq. 1 .

\subsubsection{Fin wall analysis}

As it discussed before in Hassan et al. [37], the physical discretization of the fin is one-dimensional (along the air flow direction). However, to capture the actual fin condition, it has to be virtually discretized into three portions ( $\mathrm{fp} 1, \mathrm{fp} 2$, and fp3) in the $y$-direction (along the fin height), as shown in Fig. 3a. Also, it can be noticed that each portion has its local coordinates $\left(y_{\mathrm{fp} 1}, y_{\mathrm{fp} 2}\right.$, and $\left.y_{\mathrm{fp} 3}\right)$ to simplify the analysis of fin equation. The area of each portion is specified depending on $\zeta_{1}$ and $\zeta_{2}$, which represent the boundaries between wet and dry portions. These virtual boundaries differ from one fin cell to 
t1.2 Parameter

$\mathrm{t} 1.3 U_{r, t}=1 /\left[\left(t_{t} / 2 \cdot k_{t}\right)+\left(1 / \alpha_{r, t}\right)\right]$

t1.4 $U_{\text {wet, } a, t}=1 /\left[\left(t_{t} / 2 \cdot k_{t}\right)+\left(1 / \alpha_{\text {wet, }}\right.\right.$ $a, t)]$

t1.5 $\alpha_{\text {wet, } a, t}^{a, t}=\alpha_{a, t}\left(1+\beta_{a} \cdot b_{a, t}\right)$

$\mathrm{t} 1.6 \quad \beta_{a}=h_{f g} / C_{p, m a} \cdot L e^{2 / 3}$ is the total heat transfer coefficient for the air-side under wet conditions, while $\alpha_{a, t}$ is the sensible heat transfer coefficient between the surrounding air and tube wall cell, if there is no dehumidification then $\alpha_{\mathrm{wet}, a}=\alpha_{a}$;

is a parameter resulted from using the Chilton-Colburn analogy which relates the heat and mass transfer coefficients [39];

t1.7 $b_{a, t}=\left(W_{a}-W_{\text {sat, } s, t}\right) /\left(T_{d p}-T_{s, t}\right)$ is the slope of saturation curve which is evaluated between the dew point of surrounding air and tube surface temperature; and

t1.8 $T_{a, t}^{*}=\frac{T_{a}+\beta_{a}\left[W_{a}-\left(W_{\mathrm{sat}, s, t}-b_{a, t} \cdot T_{s, t}\right)\right]}{1+\beta_{a} \cdot b_{a, t}}$ is the modified temperature for moist air, if there is no dehumidification then $T_{a, t}^{*}=T_{a}$.

another depending on the fin tip and base temperatures, and dew point of surrounding air. Consequently, the fin could be totally wet $\left(\zeta_{1}=H_{f}\right.$ and $\left.\zeta_{2}=0\right)$, totally dry $\left(\zeta_{1}=\zeta_{2}=0\right)$, or partially wet $\left(H_{f}>\zeta_{1,2} \geq 0\right)$.

According to the previous discussion, each fin cell has a piecewise governing equation (Eq. 2) which consists of three sub-functions. These sub-functions represent a continuous temperature profile for the complete fin under any dehumidifying scenario.

$\theta_{a, f}(y)\left\{\begin{array}{lll}\theta_{a, \mathrm{fp} 1}\left(y_{\mathrm{fp} 1}\right)=C_{1} e^{M \cdot y_{\mathrm{f} 1}}+C_{2} e^{-M \cdot y_{\mathrm{f} p}-\psi} & & 0 \leq y_{\mathrm{fp} 1} \leq \zeta_{1} \\ \theta_{a, \mathrm{fp} 2}\left(y_{\mathrm{fp} 2}\right)=C_{3} e^{m \cdot y_{\mathrm{f}} 2}+C_{4} e^{-m \cdot y_{\mathrm{f} 2}} & & 0 \leq y_{\mathrm{fp} 2} \leq H_{f}-\left(\zeta_{1}+\zeta_{2}\right), \\ \theta_{a, \mathrm{fp} 3}\left(y_{\mathrm{fp} 3}\right)=C_{5} e^{M \cdot y_{\mathrm{f} p}}+C_{6} e^{-M \cdot y_{\mathrm{f} \beta}-\psi}- & & 0 \leq y_{\mathrm{fp} 3} \leq \zeta_{2}\end{array}\right.$

where $\mathrm{m}=\sqrt{P_{f} \cdot \alpha_{a, f} / k_{f} \cdot A c_{f}}, M=m \sqrt{1+\beta_{a} b_{a, f}}$, and $\psi=\beta_{a}\left\{W_{a}-\left[W_{\mathrm{sat}, f}-\left(b_{a, f} T_{f}\right)\right]-b_{a, f} T_{a}\right\} / 1+\beta_{a} b_{a, f}$

$\theta_{a, f}$ represents the temperature difference between air and fin, and $\psi$ is a parameter which includes the effect of moist air humidity ratio on the fin temperature profile. $b_{a f}$ is the slope of saturation curve evaluated between the dew point of surrounding air and minimum fin root temperature [39], which can be calculated similar to $b_{a, t}$ in Table 1 . The unknown constants from $C_{1}$ to $C_{6}$ must be calculated from the boundary conditions of the heat transfer problem along the fin height. Consequently, the conditions required to calculate these constants are:

B.C. $\left\{\begin{array}{l}\theta_{a, \mathrm{fp} 1}\left(y_{\mathrm{fp} 1}=0\right)=\theta_{a, f B}=T_{a}-T_{f B}, \\ \theta_{a, \mathrm{fp} 1}\left(y_{\mathrm{fp} 1}=\zeta_{1}\right)=\theta_{a, \mathrm{fp} 2}\left(y_{\mathrm{fp} 2}=0\right), \\ \left.\frac{d \theta_{a, \mathrm{f} 1}}{d y_{\mathrm{f} 1}}\right|_{y_{\mathrm{f} 1}=\zeta_{1}}=\left.\frac{d \theta_{a, \mathrm{f} 2}}{d y_{\mathrm{fp} 2}}\right|_{y_{\mathrm{f} 2}=0}, \\ \theta_{a, \mathrm{f} \mathrm{p} 3}\left(y_{\mathrm{fp} 3}=0\right)=\theta_{a, f T}=T_{a}-T_{f T}, \\ \theta_{a, \mathrm{fp} 2}\left(y_{\mathrm{fp} 2}=H_{f}-\left(\zeta_{1}+\zeta_{2}\right)\right)=\theta_{a, \mathrm{f} 3}\left(y_{\mathrm{fp} 3}=\zeta_{2}\right), \text { and } \\ \left.\frac{d \theta_{a, \mathrm{f} 2}}{d y_{\mathrm{fp} 2}}\right|_{y_{\mathrm{f} 2}=H_{f}-\left(\zeta_{1}+\zeta_{2}\right)}=-\left.\frac{d \theta_{a, \mathrm{fp} 3}}{d y_{\mathrm{fp} 3}}\right|_{y_{\mathrm{f} \mathrm{p}}=\zeta_{2}}, \text { where } \\ \text { the negative sign in the right-hand- } \\ \text { side comes from the opposite directions of } y_{\mathrm{fp} 2} \text { and } y_{\mathrm{fp} 3} .\end{array}\right.$
Equation 2 and its boundary conditions (Eq. 3) assume uniform air temperature and humidity ratio along $y$-direction within the air cell adjacent to the evaluated fin cell. So, $\bar{T}_{a}$ and $\bar{W}_{a}$ represent the integrated mean values for air temperature and humidity ratio within the cell, respectively. The positions of $T_{f B}$ and $T_{f T}$ are shown in Fig. 3b. Therefore, it is possible to define the fin temperature profile $T_{f}$ as follows:

$$
\begin{aligned}
& T_{f}(y)=\left\{\begin{array}{l}
T_{\mathrm{fp} 1}\left(y_{\mathrm{fp} 1}\right)=\bar{T}_{a}-\theta_{a, \mathrm{fp} 1}\left(y_{\mathrm{fp} 1}\right) \\
T_{\mathrm{fp} 2}\left(y_{\mathrm{fp} 2}\right)=\bar{T}_{a}-\theta_{a, \mathrm{fp} 2}\left(y_{\mathrm{fp} 2}\right) \\
T_{\mathrm{fp} 3}\left(y_{\mathrm{fp} 3}\right)=\bar{T}_{a}-\theta_{a, \mathrm{fp} 3}\left(y_{\mathrm{fp} 3}\right)
\end{array}\right\}_{f} \\
& =\left[\mathrm{A}\left(y_{\mathrm{fp} 1}, y_{\mathrm{fp} 2}, y_{\mathrm{fp} 3}\right)\right] \cdot\left[\begin{array}{l}
\bar{T}_{a} \\
T_{f B} \\
T_{f T} \\
\bar{\psi}
\end{array}\right]
\end{aligned}
$$

where $\mathrm{A}\left(y_{\mathrm{fp} 1}, y_{\mathrm{fp} 2}, y_{\mathrm{fp} 3}\right)$ is a $3 \times 4$ matrix that depends on the local coordinates, fin geometry, dry fin parameter $\mathrm{m}$, wet fin parameter $\mathrm{M}, \zeta_{1}$, and $\zeta_{2}$.

\subsubsection{Refrigerant flow analysis}

The energy balance in each refrigerant cell $r$ in contact with $n_{t}$ tube wall cells $\left(\mathrm{t}=1-n_{t}\right)$ is explained in Eq. 5 .

$\dot{m}_{r} \cdot d h_{r}=-\sum_{t=1}^{n_{t}} \alpha_{r, t}\left(T_{r}-T_{s, t}\right) d A_{r, t}$

The total refrigerant-side pressure drop along the $x$-direction consists of frictional, acceleration, and gravitational pressure drop terms, as follows

$$
\left(\frac{d p}{d x}\right)_{r, \text { tot }}=\left(\frac{d p}{d x}\right)_{r, \text { fric }}+\left(\frac{d p}{d x}\right)_{r, \text { acc }}+\left(\frac{d p}{d x}\right)_{r, \text { grav }}
$$


Air:
In the superheat region, the single-phase total pressure drop can be expressed as:

$$
\begin{aligned}
& \left(\frac{d p}{d x}\right)_{s p, \text { tot }}=\left.\frac{f_{G}}{2} \frac{\mathrm{G}_{r}^{2}}{D_{h} \cdot \rho_{G}}\right|_{s p, \text { fric }}+\left.\mathrm{G}_{r}^{2}\left[\frac{1}{\rho_{G, \text { out }}}-\frac{1}{\rho_{G, \text { in }}}\right]\right|_{s p, \text { acc }} \text { (7) } \\
& +\left.g \rho_{G} \sin \xi\right|_{s p, \text { grav }}
\end{aligned}
$$

However, in the two-phase region, the total pressure drop for refrigerant-side can be written as:

$$
\begin{aligned}
& \left(\frac{d p}{d x}\right)_{t p, \text { tot }}=\left.\frac{d p}{d x}\right|_{t p, \text { fric }} \\
& +\left.\mathrm{G}_{r}^{2}\left\{\left[\frac{X^{2}}{\rho_{G} \cdot \Omega}+\frac{(1-X)^{2}}{\rho_{L}(1-\Omega)}\right]_{\text {out }}-\left[\frac{X^{2}}{\rho_{G} \cdot \Omega}+\frac{(1-X)^{2}}{\rho_{L}(1-\Omega)}\right]_{\text {in }}\right\}\right|_{t p, \text { acc }} \\
& +\left.g\left[\Omega \rho_{G}+(1-\Omega) \rho_{L}\right] \sin \xi\right|_{t p, \text { grav }}
\end{aligned}
$$

The void fraction $\Omega$ is modeled as a separated-flow, adopting Chisholm's correlation [40] for the slip ratio. Table 2 shows different correlations for refrigerant-side frictional pressure drop coefficient (FPDC) and heat transfer coefficient (HTC) which were applied to the current model. A comparative study between these correlations is presented later in Section 4 to find the combination which properly estimates the experimental values.

\subsubsection{Moist air flow analysis}

Equation 9 represents the heat rate balance within an air cell $a$ in contact with a fin cell $f$, which is discretized into three portions $(\mathrm{fp}=1-3)$, and $n_{t}$ tube cells

$\dot{m}_{a} \cdot C_{p, m a} \cdot d T_{a}=-\sum_{\mathrm{fp}=1}^{3} \alpha_{a, \mathrm{fp}} \cdot \theta_{a, \mathrm{fp}} \cdot d z d y_{\mathrm{fp}}-\sum_{t=1}^{n_{t}} \alpha_{a, t}\left(T_{a}-T_{s, t}\right) d A_{a, t}$

where $\theta_{a \text {,fp }}$ represents the temperature difference between surrounding air and corresponding fin portion temperature.
The mass balance, taking into account the Chilton-Colburn analogy [39], within any air cell gives:

$\dot{m}_{a} \cdot d W_{a}=\frac{1}{L e^{2 / 3} \cdot C_{p, m a}}\left[-\sum_{\mathrm{fp}=1}^{3} \alpha_{a, \mathrm{fp}} \cdot \omega_{a, \mathrm{fp}} \cdot d z d y_{\mathrm{fp}}-\sum_{t=1}^{n_{t}} \alpha_{a, t}\left(W_{a}-W_{\mathrm{sat}, s, t}\right) d A_{a, t}\right]$

where $\omega_{a, \text { fp }}$ is the humidity ratio difference between the surrounding air and saturated air evaluated at specific fin portion temperature. In Eq. 10 the air cell can only exchange mass with the tube wall cells and fin portions whose temperatures are below the dew point of the air (dehumidification process exists); otherwise, Eq. 10 is not applied and $d W_{a}=0$.

The total air-side pressure drop along the $z$-direction comprises frictional, acceleration, contraction, and expansion pressure drop terms, as follows

$$
\begin{aligned}
& \left(\frac{d p}{d z}\right)_{a, \text { tot }}=\left(\frac{d p}{d z}\right)_{a, \text { fric }}+\left(\frac{d p}{d z}\right)_{a, \text { acc }} \\
& +\left(\frac{d p}{d z}\right)_{a, \text { cont }}+\left(\frac{d p}{d z}\right)_{a, \exp }
\end{aligned}
$$

where the frictional and acceleration terms are calculated similarly to Eq. 7. The pressure drop terms due to the sudden contraction and expansion in the heat exchanger are obtained following Kays and London [43]. The correlations used to evaluate the air-side HTC and FPDC are shown in Table 2.

\subsection{Numerical scheme}

The finite volume method (FVM) was adopted to discretize the governing equations shown in the previous sub-section. In the presented governing equations, the wall temperature has been considered as the iterative variable of the problem, and the semi-explicit method for wall temperature linked equations (SEWTLE), which was proposed by Corberán et al. [50], has been applied to solve the problem. The use of the wall temperature as an independent variable gives more freedom to express explicitly the heat and mass transfer
600

\begin{tabular}{|c|c|c|c|}
\hline Fluid type & Heat transfer coefficient (HTC) & Frictional pressure drop coefficient (FPDC) & Expansion/Contraction pressure losses \\
\hline \multicolumn{4}{|l|}{ Refrigerant: } \\
\hline Single-phase & Gnielinski [41] & Churchill [42] & Kays and London [43] \\
\hline Two-phase & $\begin{array}{l}\text { - Bennett and Chen (BC) [44] } \\
\text { - Cooper (CO) [45] } \\
\text { - Hwang (HW) [10] } \\
\text { - Kandlikar and Balasubramanian (KB) [46] } \\
\text { - Wojtan et al. (WUT) [47] }\end{array}$ & $\begin{array}{l}\text { - Muller-Steinhagen and Heck (MSH) [21] } \\
\text { - Mishima and Hibiki (MH) [48] } \\
\text { - Tran et al. (TWF) [11] } \\
\text { - Lee and Mudawar (LM) [49] }\end{array}$ & Kays and London [43] \\
\hline \multicolumn{4}{|c|}{ 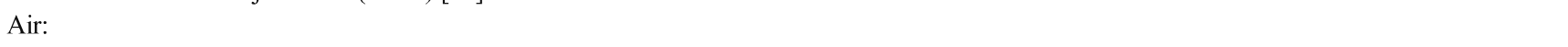 } \\
\hline Dry condition & Kim and Bullard [12] & Kim and Bullard [12] & Kays and London [43] \\
\hline Wet condition & Kim and Bullard [13] & Kim and Bullard [13] & Kays and London [43] \\
\hline
\end{tabular}

Table 2 Correlations used in the current model for coefficients evaluation 
phenomenon. Besides, it allows the formulation of equations for energy conservation with fewer assumptions compared to the classical $\varepsilon$-NTU approach. Hassan et al. [37] explained, in detail, the complete numerical scheme used to discretize the governing equations, so that in the current paper only the final discretized equations are presented.

\subsubsection{Discretization of tube wall governing equation}

The discretization of tube wall energy balance (Eq. 1) can be expressed as follows:

$$
\begin{aligned}
\lambda_{t} \cdot T_{c, t}-\sum_{k=\mathrm{W}, \mathrm{E}, \mathrm{S}, \mathrm{N}} \lambda_{t-k} \cdot T_{c, k}= & \sum_{r=1}^{n_{r}} U_{r, t}\left(\bar{T}_{r}-T_{c, t}\right) P_{r, t} \cdot \Delta x_{r, t} \\
& +\sum_{a=1}^{n_{a}} U_{\text {wet }, a, t}\left(\bar{T}_{a, t}^{*}-T_{c, t}\right) P_{a, t} \cdot \Delta z_{a, t}
\end{aligned}
$$

where

$$
\begin{aligned}
& \bar{T}_{r}=\frac{T_{r, \text { in }}+T_{r, \text { out }}}{2}, \bar{T}_{a, t}^{*}=\frac{\left.T_{a, t}^{*}\right|_{\text {in }}+\left.T_{a, t}^{*}\right|_{\text {out }}}{2}, \\
& \lambda_{t-\mathrm{W}}=\frac{k_{t} A_{t-\mathrm{W}}}{\delta l_{t-\mathrm{W}}}, \lambda_{t-\mathrm{E}}=\frac{k_{t} A_{t-\mathrm{E}}}{\delta l_{t-\mathrm{E}}}, \lambda_{t-\mathrm{S}}=\frac{k_{t} A_{t-\mathrm{S}}}{\delta l_{t-\mathrm{S}}}, \\
& \lambda_{t-\mathrm{N}}=\frac{k_{t} A_{t-\mathrm{N}}}{\delta l_{t-\mathrm{N}}}, \text { and } \lambda_{t}=\sum_{k=\mathrm{W}, \mathrm{E}, \mathrm{S}, \mathrm{N}} \lambda_{t-k} .
\end{aligned}
$$

All $\lambda_{t-k}$ terms refer to the conductance between the current tube wall cell $t$ and the adjacent tube wall cell (within $x-z$ plane) in the $k$-direction.

It is worth mentioning that in Eq. 12 the linear fluid temperature variation (LFTV) scheme was employed [50]. This scheme is based on temperature average and the assumption that the fluids temperatures, and humidity ratios in the case of moist air flow, along the fluids passes have a piecewise linear function.

\subsubsection{Discretization of fin wall governing equation}

The fin temperature profile (Eq. 4) after discretization can be illustrated as:

$$
\bar{\theta}_{a, f}=\left\{\begin{array}{l}
\bar{\theta}_{a, \mathrm{fp} 1} \\
\bar{\theta}_{a, \mathrm{fp} 2} \\
\bar{\theta}_{a, \mathrm{fp} 3}
\end{array}\right\}_{a, f}=\left\{\begin{array}{l}
\bar{T}_{a}-\bar{T}_{\mathrm{fp} 1} \\
\bar{T}_{a}-\bar{T}_{\mathrm{fp} 2} \\
\bar{T}_{a}-\bar{T}_{\mathrm{fp} 3}
\end{array}\right\}=[B] \cdot\left[\begin{array}{l}
\bar{T}_{a} \\
T_{f B} \\
T_{f T} \\
\bar{\psi}
\end{array}\right]
$$

where [B] is a $3 \times 4$ matrix that depends on fin geometry, dry fin parameter $m$, wet fin parameter $M, \zeta_{1}$, and $\zeta_{2}$. Complete evaluation of the elements of this matrix was introduced in [37] (Appendix A).

\subsubsection{Discretization of refrigerant flow governing equation}

Equation 14 represents the discretization of energy balance within any refrigerant cell (Eq. 5)

$T_{r, \text { out }}=\frac{T_{r, \text { in }}\left(1-0.5 \sum_{t=1}^{n_{t}} \mathrm{NTU}_{r, t}\right)+\sum_{t=1}^{n_{t}} \mathrm{NTU}_{r, t} \cdot T_{s, t}}{\left(1+0.5 \sum_{t=1}^{n_{t}} \mathrm{NTU}_{r, t}\right)}$

where $\mathrm{NTU}_{r, t}=\frac{\alpha_{r, t} \cdot A_{r, t}}{m_{r} \cdot \bar{C}_{p, r}}$.

Equation 14 is used for a one-phase flow, whereas for twophase flow the outlet temperature depends on the outlet pressure.

\section{3. $\sum^{n} .4$ Discretization of moist air flow governing equations}

$f=1$
Based on Eqs. 9 and 10 and considering the fin temperature profile (Eq. 13), the following expressions represent the average air temperature and humidity ratio, subsequently the outlet air temperature and humidity ratio, within any moist air cell.

$$
\begin{aligned}
& \bar{T}_{a}\left\{2+\mathrm{NTU}_{a, \mathrm{fp} 1} \cdot B_{1,1}+\mathrm{NTU}_{a, \mathrm{fp} 2} \cdot B_{2,1}+\mathrm{NTU}_{a, \mathrm{f} 3} \cdot B_{3,1}+\sum_{t=1}^{n_{t}} \mathrm{NTU}_{a, t}\right\}= \\
& \left\{\begin{array}{l}
2 T_{a}^{\mathrm{in}}-\left[\mathrm{NTU}_{a, \mathrm{fp} 1} \cdot B_{1,2}+\mathrm{NTU}_{a, \mathrm{fp} 2} \cdot B_{2,2}+\mathrm{NTU}_{a, \mathrm{f} 3} \cdot B_{3,2}\right] T_{f B}- \\
{\left[\mathrm{NTU}_{a, \mathrm{fp} 1} \cdot B_{1,3}+\mathrm{NTU}_{a, \mathrm{fp} 2} \cdot B_{2,3}+\mathrm{NTU}_{a, \mathrm{fp} 3} \cdot B_{3,3}\right] T_{f T^{-}}} \\
{\left[\mathrm{NTU}_{a, \mathrm{fp} 1} \cdot B_{1,4}+\mathrm{NTU}_{a, \mathrm{fp} 2} \cdot B_{2,4}+\mathrm{NTU}_{a, \mathrm{fp} 3} \cdot B_{3,4}\right] \bar{\psi}+\sum_{t=1}^{n_{t}} \mathrm{NTU}_{a, t} \cdot T_{s, t}}
\end{array}\right\}
\end{aligned}
$$

$$
\bar{T}_{a}=\frac{T_{a}^{\mathrm{in}}+T_{a}^{\text {out }}}{2}, \mathrm{NTU}_{a, \mathrm{fp}}=\frac{\alpha_{a, \mathrm{fp}} \cdot A_{a, \mathrm{fp}}}{\dot{m}_{a} \cdot \bar{C}_{p, m a}, \text { and } \mathrm{NTU}_{a, t}=\frac{\alpha_{a, t} \cdot A_{a, t}}{\dot{m}_{a} \cdot \bar{C}_{p, m a}}} \quad(\text { where })
$$

$\bar{W}_{a}\left\{2+\mathrm{NMTU}_{a, \text { fp } 1}+0+\mathrm{NMTU}_{a, \mathrm{fp} 3}+\sum_{i=1}^{n_{t}} \mathrm{NMTU}_{a, t}\right\}=$

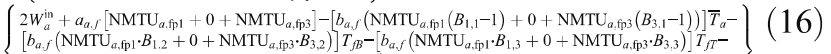

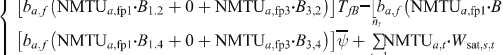

$$
\begin{aligned}
& \bar{W}_{a}=\frac{W_{a}^{\mathrm{in}}+W_{a}^{\text {out }}}{2}, \mathrm{NMTU}_{a, \mathrm{fp}} \\
& =\frac{\alpha_{a, \mathrm{fp}} \cdot A_{a, \mathrm{fp}}}{\dot{m}_{a} \cdot \bar{C}_{p, m a} \cdot L e^{2 / 3}, \text { and } \mathrm{NMTU}_{a, t}=\frac{\alpha_{a, t} \cdot A_{a, t}}{\dot{m}_{a} \cdot \bar{C}_{p, m a} \cdot L e^{2 / 3}}}
\end{aligned}
$$

(where)

\subsection{Solution methodology}

Figure 4 represents the solution methodology and procedures applied in the current model.

After the initialization process, the iteration process begins, which consists of three main steps. The first step is to calculate the outlet temperatures for all fluids cells using Eq. 14 for refrigerant flow, and Eq. 15 for moist air flow. Afterwards, Eq. 16 is used to calculate the moist air outlet humidity ratios. In the first iteration the dehumidifying condition of the fin has not yet been 
evaluated, so that the fin is assumed to be totally dry. The second step is to calculate the tube wall cells temperatures using Eq. 12. It can be observed that this equation considers the $2 \mathrm{D}$ heat conduction between the current tube wall cell and neighboring cells, which results in a system of linear equations involving all the tube wall cells temperatures. To solve this system of equations, the line-byline iteration method is adopted in the current model [51]. This method converts the system of equations into a set of explicit linear equations, which can be solved easily.

The third step of the iteration process is to evaluate the dehumidifying condition of each fin cell (either to be totally dry, totally wet, or partially wet) then calculate its average temperature. Firstly, the fin cell dehumidifying condition is evaluated according to the fin cell roots temperatures and average dew point temperature of the surrounding air. After identifying the real fin cell condition, $\zeta_{1}$ and $\zeta_{2}$ are calculated using Eqs. 17 and 18, respectively. Secondly, the exact length for each fin portion (fp1, fp2, and fp3) is calculated based on $\zeta_{1}$, $\zeta_{2}$, and $H_{f}$.

$\zeta_{1}=\frac{1}{m} \cdot \ln$
$=\left\{\begin{array}{l}\frac{-1}{2\left(\theta_{a, f r} e^{m H_{f}}-\theta_{a, \beta}\right)} \times \\ \end{array}\right.$
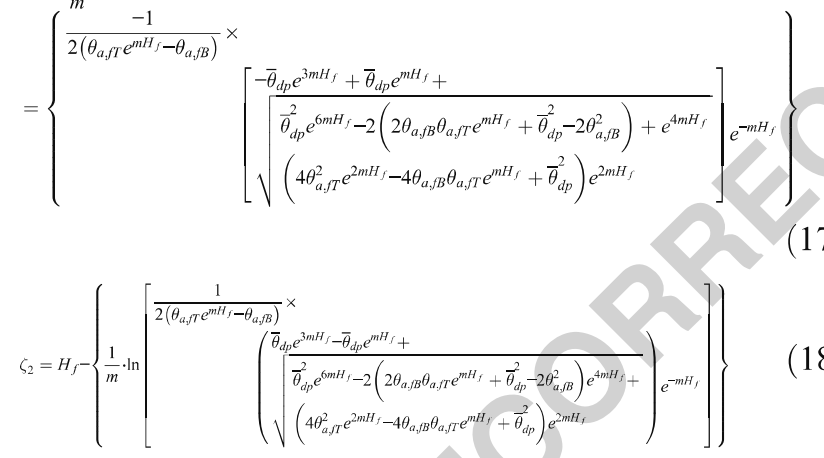

$\bar{\theta}_{d p}=\bar{T}_{a}-\bar{T}_{d p}, \theta_{a, f B}=\bar{T}_{a}-T_{f B}$, and $\theta_{a, f T}=\bar{T}_{a}-T_{f T}$. (where)

Finally, the average fin cell temperature is determined using Eq. 13. It can be noticed that there is no longitudinal heat conduction in the fin along the $z$-direction, subsequently the fin wall temperature calculations do not need any iterative procedures. Based on this, the fin wall temperature field is obtained explicitly. The iterative process continues till the value of the residual converges to the required tolerance.

\section{Experimental setup}

The experiments were carried out in a reversible air-torefrigerant heat pump test facility, as shown in Fig. 5, which mainly consists of three circuits: air, water, and refrigerant loops. The heat pump operates with $\mathrm{R}-134 \mathrm{a}$ and it is equipped with: a multi-speed hermetic

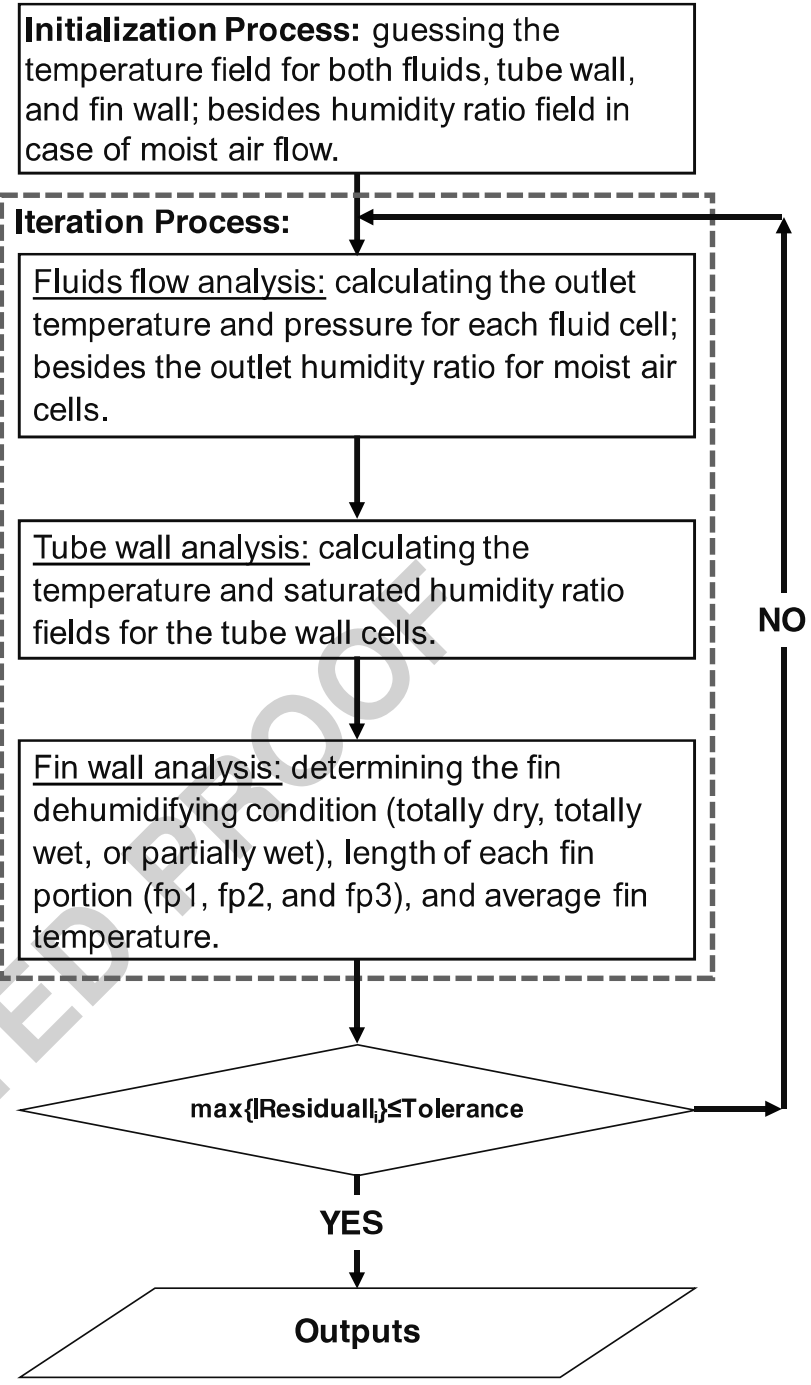

Fig. 4 Flowchart of the presented evaporator model (MCHX-1D-MB)

reciprocating compressor with a displacement of $34.38 \mathrm{~cm}^{3}$, a brazed plate condenser (water-to-refrigerant), an electronic valve as the expansion device, and finally, an aluminum minichannel evaporator (Table 3 lists its main specifications). The operating conditions, which were specified as input data for the tested evaporator, are summarized in Table 4. The energy balance between the evaporator's air- and refrigerant-side was within $\pm 10 \%$ error bands, with a mean absolute relative deviation (MARD) of $\pm 6 \%$, where

$$
\begin{aligned}
& \text { MARD }\left.\right|_{\text {cooling capacity }} \\
& =\left(\frac{1}{\text { Experimental points }\left(\mathrm{n}_{\mathrm{exp}}\right)} \sum_{1}^{\mathrm{n}_{\text {eqp }}}\left|\frac{\text { Air-side capacity-Refrigerant-side capacity }}{\text { Refrigerant-side capacity }}\right|\right) \times 100
\end{aligned}
$$

Table 5 provides the range of measurements and corresponding maximum uncertainties. 


\section{Model validation and discussion}

\subsection{Model validation with R-134a minichannel evaporator results}

The numerical grid size chosen was the one that gave a good balance between accuracy and computational cost. According to the previous grid definition and Fig. 2, the discretization grid employed for all the predicted results was: $\{5,3,3,3\}$. For humid air, Lewis number is usually close to unity (ranged from 0.8 to 0.9 ). Also, it is relatively insensitive to variations in temperature [52], so a Lewis number of unity was assumed in the whole validation.

As previously mentioned, different combinations of refrigerant-side FPDC and HTC correlations (Table 2) were applied to find the most suitable one that gives the best predictions regarding the heat transfer rates and pressure drop values. Whereas, Kim and Bullard correlations [12,13] were used for the air-side calculations. These correlations are recommended by many authors in the literature to evaluate the performance of such type of fin (multi-louvered) $[1,2,5,53]$.

For nomenclature representation, abbreviations for the refrigerant-side correlations have been proposed, as shown in Table 2. The combination of refrigerant-side correlations is illustrated as, the abbreviation of FPDC correlation + the abbreviation of HTC correlation.

The input parameters to the model were refrigerant superheat, inlet quality, inlet air temperature and relative humidity, and inlet mass flow rates of refrigerant and air. Whereas, the inlet saturation temperature, refrigerant-side pressure drop, outlet air temperature, and cooling capacity were the selected parameters to validate the proposed model.

Figure 6 compares the calculated inlet saturation temperatures $\mathrm{T}_{\mathrm{r} \text {,sat,in }}$ with the measured ones for different refrigerantside FPDC and HTC correlations. It can be observed (Fig. 6a and b) that the best combinations are $\mathrm{MH}+\mathrm{KB}$ and $\mathrm{LM}+\mathrm{CO}$, they predicted quite well the inlet saturation temperature values within $\pm 0.5^{\circ} \mathrm{C}$ error bands, with nearly similar mean absolute error (MAE) values of \pm 0.239 and $\pm 0.237{ }^{\circ} \mathrm{C}$, respectively. In the current study the MAE is calculated as:

$\operatorname{MAE}\left\{\begin{array}{l}=\frac{1}{\text { Experimental points }\left(\mathrm{n}_{\mathrm{exp}}\right)} \sum_{1}^{n_{\text {exp }}} \mid \text { Predicted value-Measured value|, as a mean absolute difference } \\ =\left(\frac{1}{\text { Experimental points }\left(\mathrm{n}_{\mathrm{exp}}\right)} \sum_{1}^{n_{\text {exp }}}\left|\frac{\text { Predicted value-Measured value }}{\text { Measured value }}\right|\right) \times 100 \text {, as a mean absolute percentage }\end{array}\right.$

The calculated refrigerant-side pressure drop $\Delta \mathrm{p}_{\mathrm{r}}$ against the measured data is depicted in Fig. 7, for different HTC and FPDC correlations. It can be seen that the combinations of $\mathrm{MH}+\mathrm{KB}$ (Fig. 7a), $\mathrm{MH}+\mathrm{CO}$ (Fig. 7b), and $\mathrm{LM}+\mathrm{CO}$ (Fig. $7 \mathrm{~b})$ give the most appropriate prediction results for the $\Delta \mathrm{p}_{\mathrm{r}}$. They successfully estimated the data within $\pm 20 \%$ error bands, with MAE values of $\pm 9.12, \pm 9.98$, and $\pm 10.02 \%$, respectively.

It can be concluded from the previous results that the combination of $\mathrm{MH}+\mathrm{KB}$ is the most appropriate one for refrigerant-side calculations in the current study. Based on $\mathrm{MH}+\mathrm{KB}$ combination, and Kim and Bullard correlations

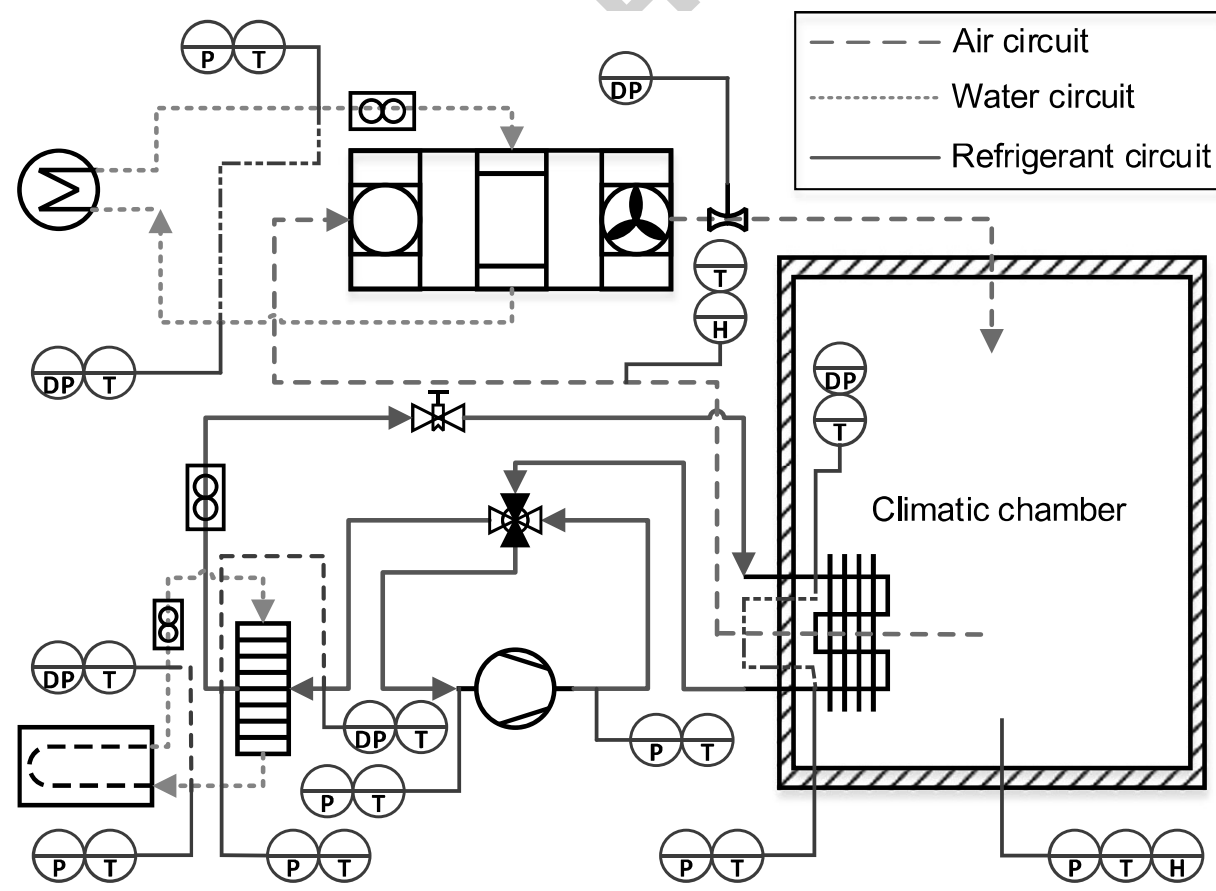

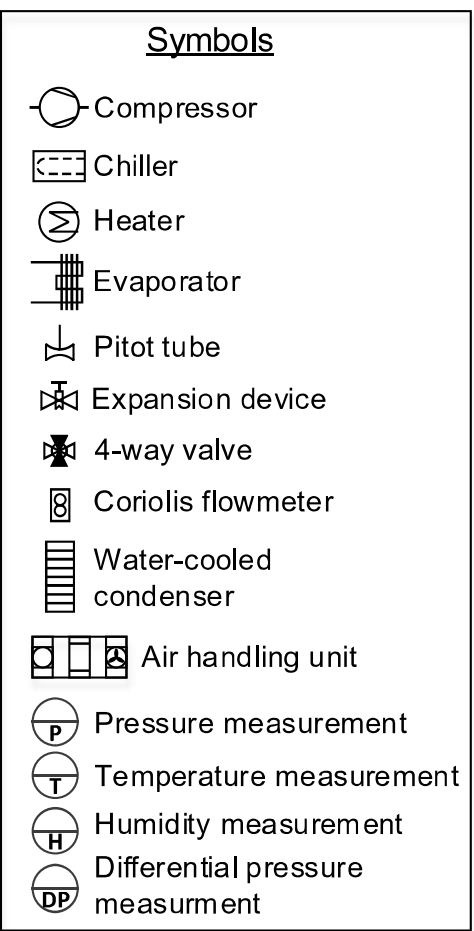

Fig. 5 Schematic diagram of the test facility for the R-134a air-to-refrigerant heat pump 
Table 3 R-134a minichannel evaporator's specifications

\begin{tabular}{lll} 
t3.2 & Core height $(\mathrm{mm})$ & 335.49 \\
t3.3 & Core length (finned length) $(\mathrm{mm})$ & 483.3 \\
t3.4 & Core depth (air-flow direction) $(\mathrm{mm})$ & 18.8 \\
t3.5 & Number of slabs & 1 \\
t3.6 & Face area $\left(\mathrm{m}^{2}\right)$ & 0.1606 \\
t3.7 & Total air-side area $\left(\mathrm{m}^{2}\right)$ & 2.6678 \\
t3.8 & Tube major (air-flow direction) $(\mathrm{mm})$ & 18.8 \\
t3.9 & Tube minor (mm) & 1.93 \\
t3.10 & Number of tubes & 33 \\
t3.11 & Number of passes/(tubes per pass) & $4 /(8-6-7-12)$ \\
t3.12 & Number of ports per tube & 8 \\
t3.13 & Port shape & Triangular \\
t3.14 & Port hydraulic diameter $(\mathrm{mm})$ & 0.78 \\
t3.15 & Fin type & Multi-louvered \\
t3.16 & Fin thickness (mm) & 0.1 \\
t3.17 & Fin height (mm) & 7.33 \\
t3.18 & Fin density (fpi) & 14 \\
\cline { 2 - 2 } & &
\end{tabular}

$[12,13]$, Figs. 8 and 9 compare the predicted outlet air temperature $\mathrm{T}_{\mathrm{a} \text {,out }}$ and mass flow rate of condensed water ${ }_{\mathrm{w}}{ }_{\mathrm{w}}$ with the experimental measurements, respectively.

Figure 8 shows that the proposed model predicted the outlet air temperatures within $\pm 0.5{ }^{\circ} \mathrm{C}$ error bands, with a MAE of $\pm 0.43{ }^{\circ} \mathrm{C}$. On the other hand, it can be seen in Fig. 9 that the predicted values of mass flow rate of condensed water are within $\pm 10 \%$ error bands, with a MAE of $\pm 5.4 \%$.

The good prediction of inlet saturation temperatures, outlet air temperatures, and water condensation rates has a positive impact on the predicted cooling capacity as shown in Fig. 10. It can be clearly noticed that the predicted values of cooling capacity are within $\pm 5 \%$ error bands.

\subsection{Model validation with $\mathrm{CO}_{2}$ minichannel evaporator results}

The experimental results of Beaver et al. [54] were used to validate the current model against minichannel evaporator employed in a transcritical $\mathrm{CO}_{2}$ air-conditioning system. The characteristics of target evaporator and test conditions are summarized in Tables 6 and 7, respectively.

This range of conditions allows simulating the evaporator under different dry and wet conditions. The inlet refrigerant pressure, inlet vapor quality, inlet air temperature and relative humidity, and inlet mass flow rates for air and refrigerant were selected, in the current study, as inputs for the presented model. On the other hand, the cooling capacity, refrigerant-side pressure drop, and outlet air temperature are the outputs which were selected for the validation.
In this study, the correlation of Tran et al. [11] (TWF) was utilized to predict the $\mathrm{CO}_{2}$ frictional pressure drop coefficient. This correlation was selected based on the recommendation of Kim and Bullard [1] who compared between many FPDC correlations for their $\mathrm{CO}_{2}$ minichannel evaporator model. However, to predict a proper value of refrigerant-side HTC, different correlations were applied, see Table 2. Kim and Bullard correlations $[12,13]$ were kept to estimate the airside HTC and FPDC.

Figure 11 shows the calculated cooling capacity values versus the measured ones for different refrigerant-side HTC correlations. It can be observed that the combination of $\mathrm{TWF}+\mathrm{KB}$ successfully estimated the cooling capacity within $\pm 10 \%$ error bands, with a MAE of $\pm 4.3 \%$.

According to the previous results, the ratios of predicted to measured refrigerant-side pressure drop versus the refrigerant mass flow rate values are illustrated in Fig. 12. Generally, the proposed model underpredicted the refrigerant-side pressure drop compared to the experimental data. However, the maximum deviation between the predicted and measured values was $11 \mathrm{kPa}$ (corresponds to a deviation of $\approx 0.1 \mathrm{~K}$ in the evaporation temperature).

Finally, Fig. 13 compares the calculated outlet air temperature values with the measured values. It can be noticed that approximately $60 \%$ of the predicted data are within $\pm 1.0^{\circ} \mathrm{C}$ error bands with a MAE of $\pm 0.9^{\circ} \mathrm{C}$, while the rest are within $\pm 2.0{ }^{\circ} \mathrm{C}$ error bands.

\section{Effect of fin cutting on the air-side performance of minichannel evaporators}

The cut fin is a widely used assumption in modeling the heat exchangers to simplify the solution $[1-5,7]$. It assumes that the fin is cut at half the height. Subsequently, it results to two separate fin portions with adiabatic-tips, as shown in Fig. 14.

To understand the influence of cut fin assumption on the air-side performance of minichannel evaporators, a new model was developed (MCHX-1D-CF). The discretization scheme and governing equations used in MCHX-1D-CF model are almost similar to the ones adopted by the MCHX-1D-MB model, except the fin discretization along $y$-direction (fin height). As it can be seen in Fig. 14, the middle fin portion (fp2) is omitted and the fin cell is discretized into two equal portions ( $\mathrm{fp} 1=$ $\mathrm{fp} 3=\mathrm{H}_{\mathrm{f}} / 2$ ). It is worth mentioning that the concept of moving boundary, to distinguish between wet and dry zones along the fin height, is no longer used in the MCHX-1D-CF model. Instead of this, each fin portion is evaluated separately, it could be totally dry or wet based on fin base temperature and dew point temperature of surrounding air. 
t4.1 Table 4 Operating conditions for the tested R-134a minichannel evaporator

\begin{tabular}{llcl} 
t4.2 & Air & & Refrigerant \\
\cline { 2 - 4 } $\mathrm{t} 4.3$ & Inlet dry-bulb temperature $\left({ }^{\circ} \mathrm{C}\right)$ & 7 & Inlet mass flow rate $(\mathrm{kg} / \mathrm{h})$ \\
$\mathrm{t} 4.4$ & Inlet relative humidity $(\%)$ & $73-90$ & Inlet vapor quality $(-)$ \\
$\mathrm{t} 4.5$ & Inlet flow rate $\left(\mathrm{m}^{3} / \mathrm{h}\right)$ & $890-1890$ & Outlet superheat $(\mathrm{K})$
\end{tabular}

t5.1 Table 5 Measured parameters and uncertainty

\begin{tabular}{|c|c|c|c|}
\hline Measured parameters & Device & Measuring range & Maximum uncertainty \\
\hline Temperature & Pt100 RTD class A 1/10 DIN & $223-523 \mathrm{~K}$ & $\pm 0.1 \mathrm{~K}$ \\
\hline Absolute pressure & Piezoresistive sensor & $0-1600 \mathrm{kPa}$ & $\pm 14.6 \mathrm{kPa}$ \\
\hline Differential pressure & Capacitive sensor & $-249-248 \mathrm{kPa}$ & $\pm 0.54 \mathrm{kPa}$ \\
\hline Refrigerant mass flow rate & Coriolis flow meter & $0-2178 \mathrm{~kg} / \mathrm{h}$ & $\pm 0.5 \mathrm{~kg} / \mathrm{h}$ \\
\hline Air flow rate & Venturi tube and differential pressure capacitive sensor & $0.083-0.972 \mathrm{~m}^{3} / \mathrm{s}$ & $\pm 0.021 \mathrm{~m}^{3} / \mathrm{s}$ \\
\hline Air relative humidity & Capacitive humidity sensor & $0-100 \%$ & $\pm 3.35 \%$ \\
\hline Compressor power consumption & Electrical measuring transducer & $0-1500 \mathrm{~W}$ & $\pm 8.66 \mathrm{~W}$ \\
\hline
\end{tabular}

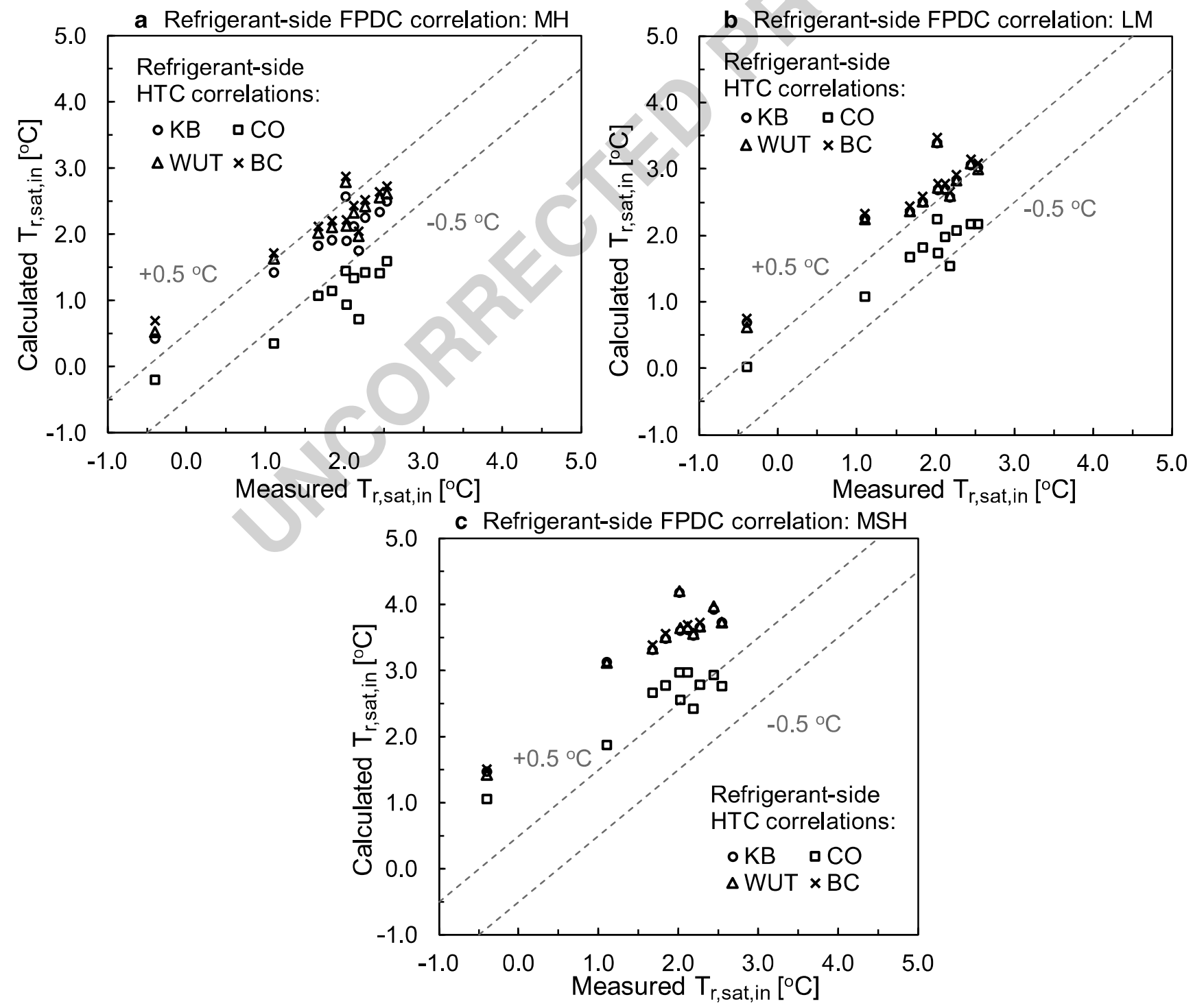

Fig. 6 Comparison of calculated and measured inlet saturation temperatures $\mathrm{T}_{\mathrm{r} \text {,sat,in }}$ for the tested R-134a minichannel evaporator 

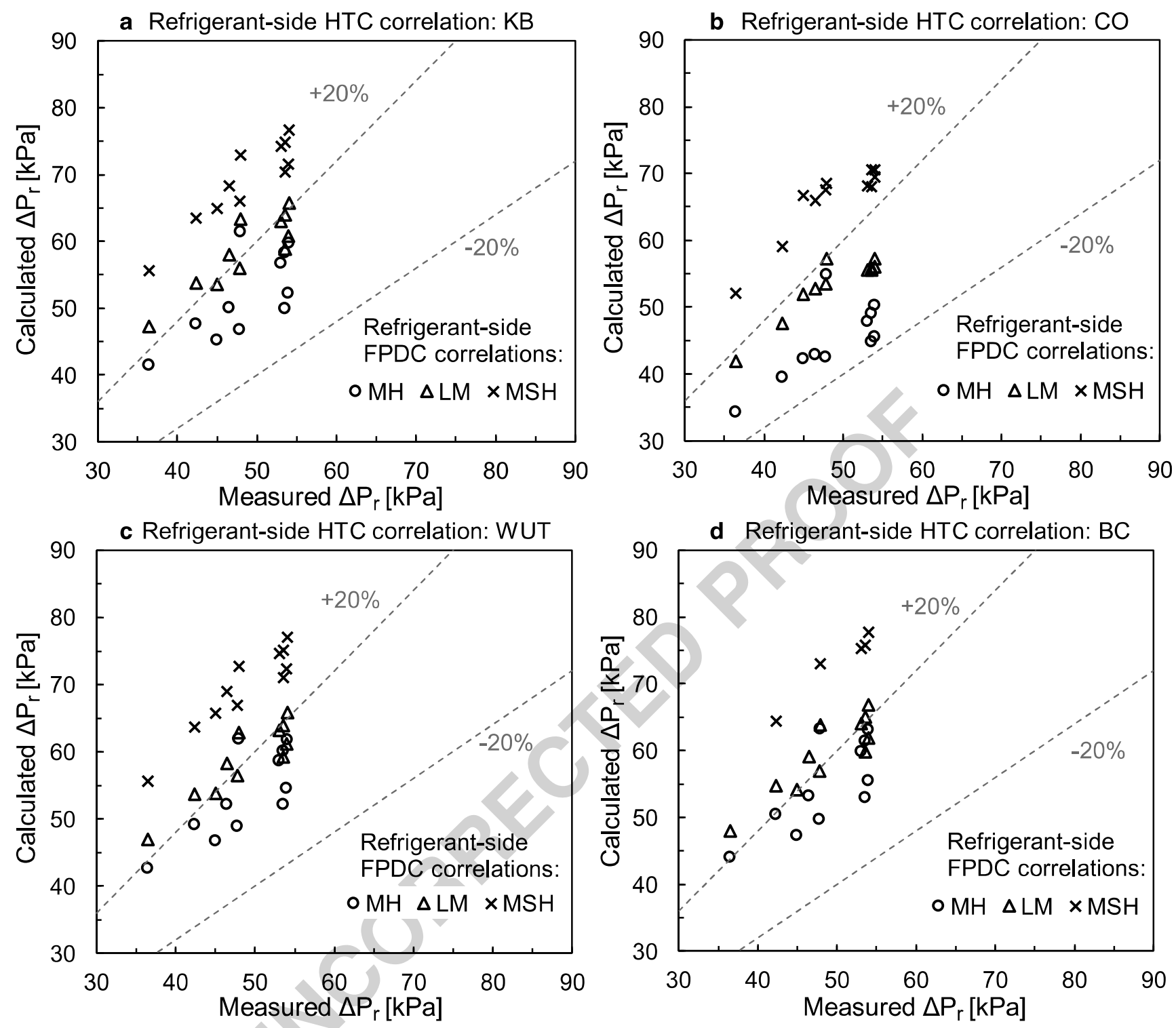

Fig. 7 Comparison of calculated and measured refrigerant-side pressure drop $\Delta p_{r}$ values for the tested R-134a minichannel evaporator

A comparative study between the presented numerical models was implemented using the same R-134a minichannel evaporator and operating conditions which were adopted in the validation study. The inlet air temperature, air volume flow rate, inlet refrigerant quality, and refrigerant mass flow rate were fixed at $7{ }^{\circ} \mathrm{C}, 1500$ $\mathrm{m}^{3} / \mathrm{h}, 0.23$, and $36.5 \mathrm{~kg} / \mathrm{h}$, respectively. While, the inlet air relative humidity was varied from 95 to $60 \%$, this allowed evaluating the evaporator performance under different dehumidifying scenarios (totally wet, partially wet, and totally dry conditions).

Figure 15 illustrates the absolute relative deviation (ARD) values in latent and sensible heat transfer rates as a function of inlet air relative humidity. It should be noted that the ARD values were calculated relative to MCHX1D-MB model results. As it can be seen in Fig. 15, the results are divided to three main regions, based on the MCHX-1D-MB model predictions. In the totally wet region, the entire evaporator operates under fully wet conditions. It can be observed that the deviations between the proposed models are only up to $\approx 0.8 \%$. At the first prediction of a partially wet fin cell, the partially wet region comes into action. This region is divided further to two sub-zones. In sub-zone 1 , the deviations in partially wet region begins to increase clearly with the decrease in inlet air relative humidity till reaching $\approx 12 \%$ at $\mathrm{RH}_{\mathrm{a} \text {,in }}=71 \%$. Regarding the second sub-zone, despite the deviations between the current models exponentially increase up to 


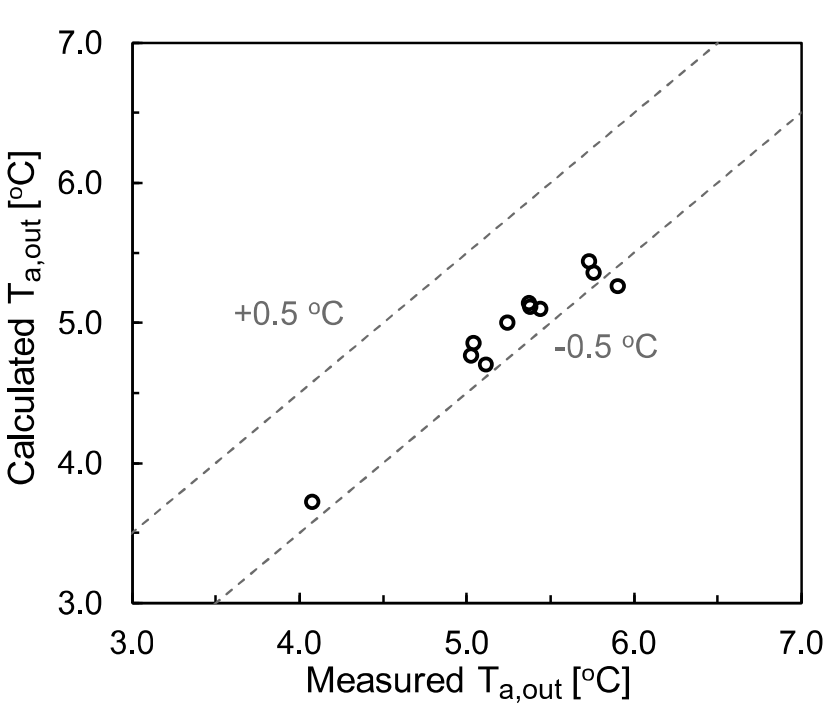

Fig. 8 Predicted vs. measured outlet air temperatures $T_{a, \text { out }}$ for the tested R-134a minichannel evaporator $\approx 48 \%$, they do not have any significant effects on the total air-side heat transfer rates because of neglected contribution of latent heat transfer within this zone. Therefore, sub-zone 2 is considered to be a transition region between partially wet and totally dry regions, which could be ignored without any important impacts on the current comparative study. Finally, the totally dry region starts once the latent heat transfer rate equals zero.

On the other hand, the relative deviations in sensible heat transfer rate between MCHX-1D-CF and MCHX-1DMB models are insignificant, as it can be concluded from Fig. 15. These deviations reach a maximum value of

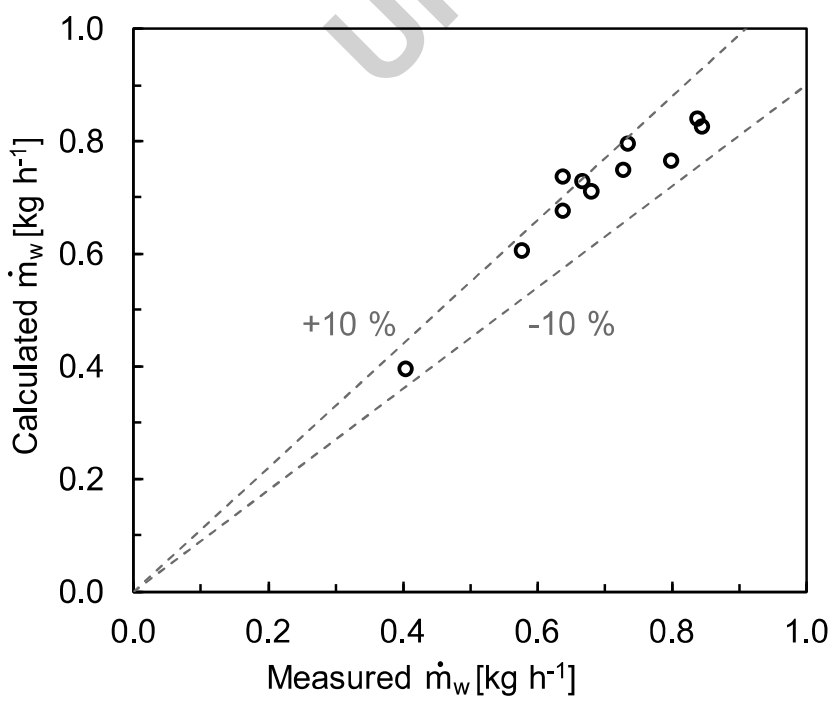

Fig. 9 Predicted vs. measured values of mass flow rate of condensed water $\mathrm{m}_{\mathrm{w}}$ for the tested R-134a minichannel evaporator

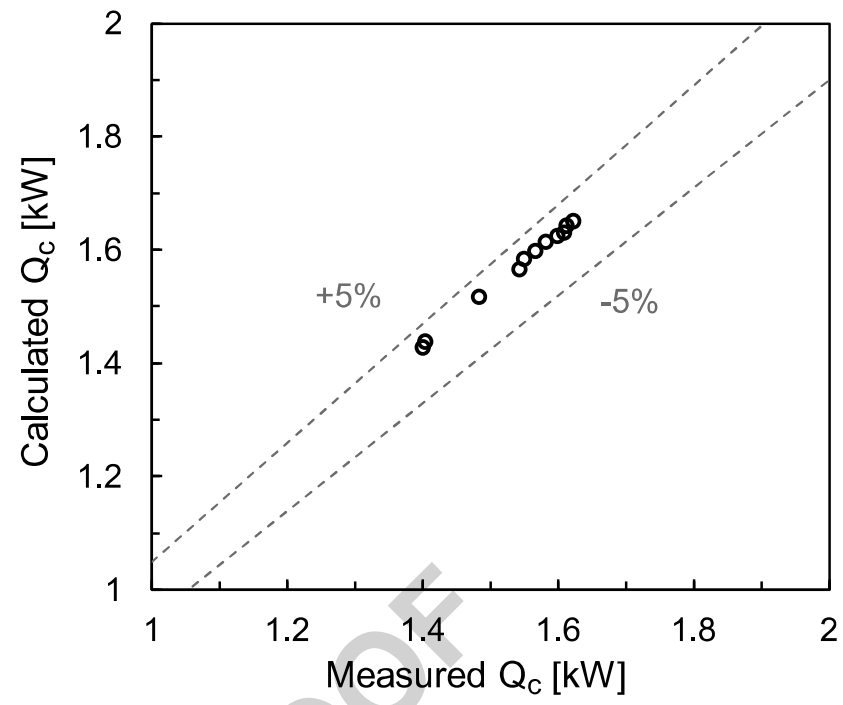

Fig. 10 Predicted vs. measured values of cooling capacity $Q_{c}$ for the tested R-134a minichannel evaporator

$\approx 1.1 \%$. It is worth mentioning that Martínez-Ballester et al. [53] reported similar results in their comparative study regarding the impact of cut fin assumption on the sensible heat transfer rate for minichannel gas coolers and condensers.

To understand more the sources of deviations between the current models in the partially wet region, a comparison between different fin temperature profiles is presented in Fig. 16. These temperature profiles were obtained at $76 \%$ inlet air relative humidity. At this specific value, approximately half of the total number of fin cells was
Table $6 \quad \mathrm{CO}_{2}$ minichannel evaporator's characteristics [54]

\begin{tabular}{ll}
\hline Core height (mm) & 440 \\
Core length (finned length) $(\mathrm{mm})$ & 820 \\
Number of slabs & 1 \\
Face area $\left(\mathrm{m}^{2}\right)$ & 0.36 \\
Total air-side area $\left(\mathrm{m}^{2}\right)$ & 7.926 \\
Tube major (air-flow direction) $(\mathrm{mm})$ & 16.51 \\
Tube minor (mm) & 1.65 \\
Number of tubes & 41 \\
Number of passes/(tubes per pass) & $1 / 41$ \\
Number of ports per tube & 11 \\
Port shape & Circular \\
Port diameter (mm) & 0.79 \\
Fin type & Multi-louvered \\
Fin thickness (mm) & 0.1 \\
Fin height (mm) & 8.9 \\
Fin density (fpi) & 17 \\
\hline
\end{tabular}


Heat Mass Transfer

\begin{tabular}{lllll} 
t7.1 & Table 7 & Test conditions for the $\mathrm{CO}_{2}$ minichannel evaporator [54] \\
\cline { 2 - 4 } t7.2 & Air & Refrigerant & \\
\cline { 2 - 4 } t7.3 & $\begin{array}{l}\text { Inlet dry-bulb } \\
\text { temperature }\left({ }^{\circ} \mathrm{C}\right)\end{array}$ & 26.5 & $\begin{array}{c}\text { Inlet mass flow } \\
\text { rate }(\mathrm{kg} / \mathrm{h})\end{array}$ & $127-170$ \\
$\mathrm{t} 7.4$ & $\begin{array}{c}\text { Inlet relative } \\
\text { humidity }(\%)\end{array}$ & $14-55$ & $\begin{array}{c}\text { Inlet vapor } \\
\text { quality }(-)\end{array}$ & $0.16-0.4$ \\
t7.5 & $\begin{array}{c}\text { Inlet flow rate } \\
\left(\mathrm{m}^{3} / \mathrm{h}\right)\end{array}$ & $2000-2450$ & $\begin{array}{c}\text { Inlet pressure } \\
(\mathrm{kPa})\end{array}$ & $4100-5000$ \\
\end{tabular}

estimated to be under partially wet conditions. It can be clearly noticed from Fig. 16 that MCHX-1D-CF model always underestimates the fin temperature profile compared to MCHX-1D-MB model. This is a consequence of cutting the fin at half the height; which, in turn, prevents the heat conduction between adjacent tubes through the fin. This underestimation of fin temperature profile results to a misprediction of the actual dehumidifying condition of the fin. This, sequentially, has a direct impact on the latent heat transfer rate calculations, and results to these noticeable deviations between the two models in the partially wet region.

It should be mentioned that in the current study the fin parameter $\left(m \cdot H_{f}\right)$ ranges between 0.9 and 1.0. This is the main parameter that affects the fin efficiency and its overall thermal performance. It is expected that the deviations in the air-side heat transfer rates between the MCHX-1D-CF and MCHX-1D-MB models will increase further with the increase in fin parameter.

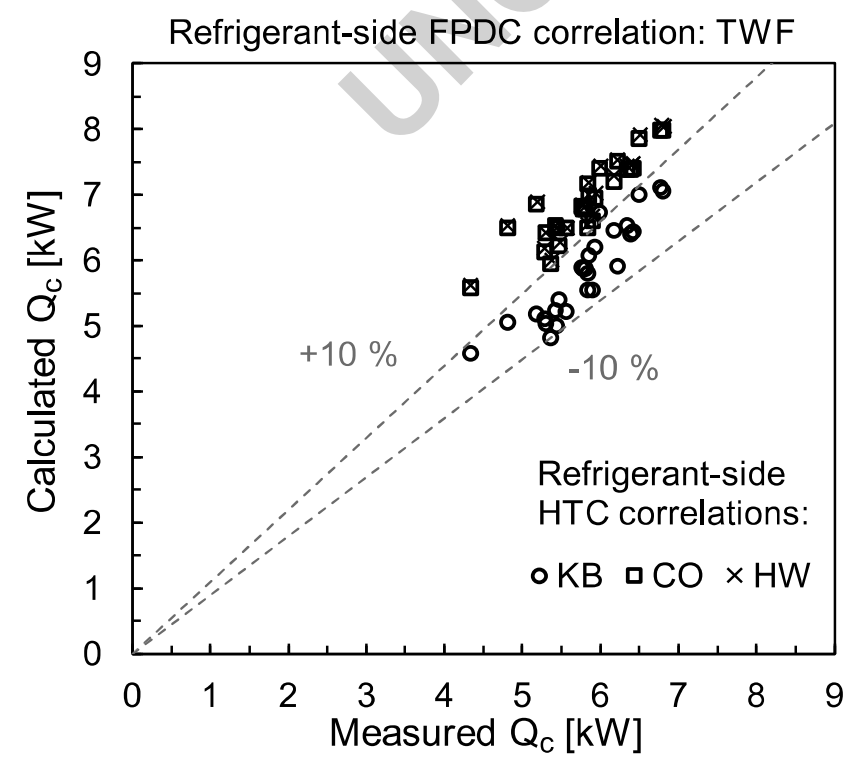

Fig. 11 Comparison between the calculated cooling capacity $\mathrm{Q}_{\mathrm{c}}$ values and measured values of Beaver et al. [54]

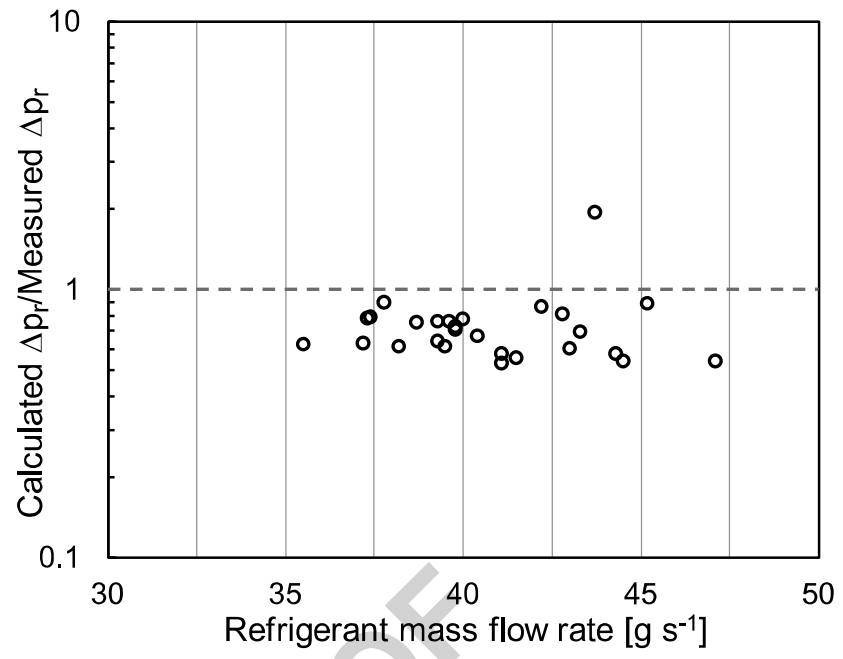

Fig. 12 Ratio of predicted to measured refrigerant-side pressure drop vs. refrigerant mass flow rate for the $\mathrm{CO}_{2}$ minichannel evaporator

\section{Summary and conclusions}

A minichannel evaporator model (MCHX-1D-MB) was developed and successfully validated against experimental data for different operating conditions. The main features and advantages of the proposed model are: continuous temperature profile along the fin height (even under partial dehumidification scenarios), accounting for the heat conduction between adjacent tubes through the fin (no utilization of cut fin assumption), predicting precisely the fin dehumidifying condition (totally dry, various scenarios of partially wet, or totally wet fin), and simple modeling technique with short calculation time.

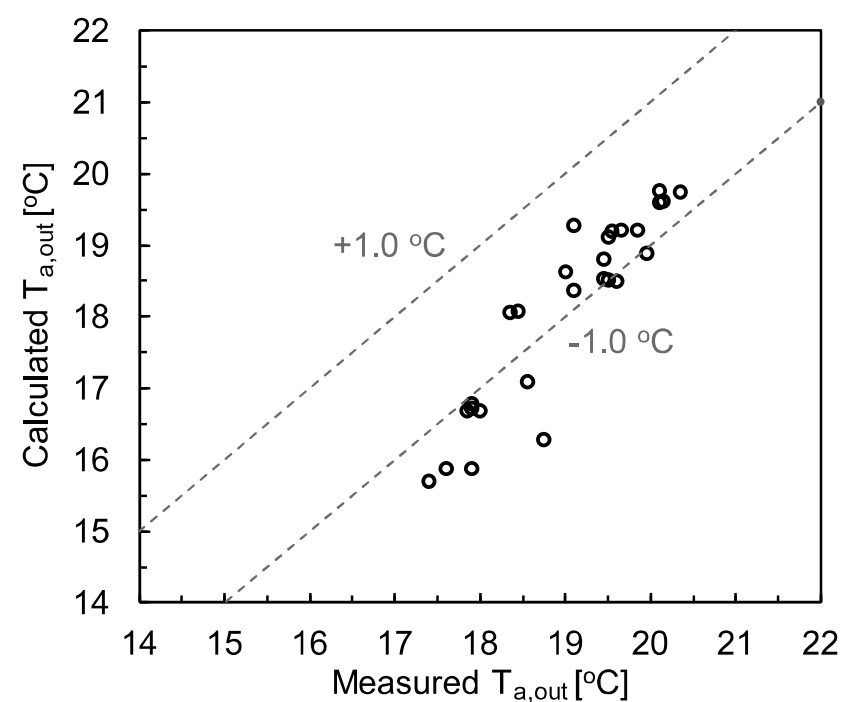

Fig. 13 Predicted vs. measured outlet air temperatures $T_{a, \text { out }}$ of Beaver et al. [54] 


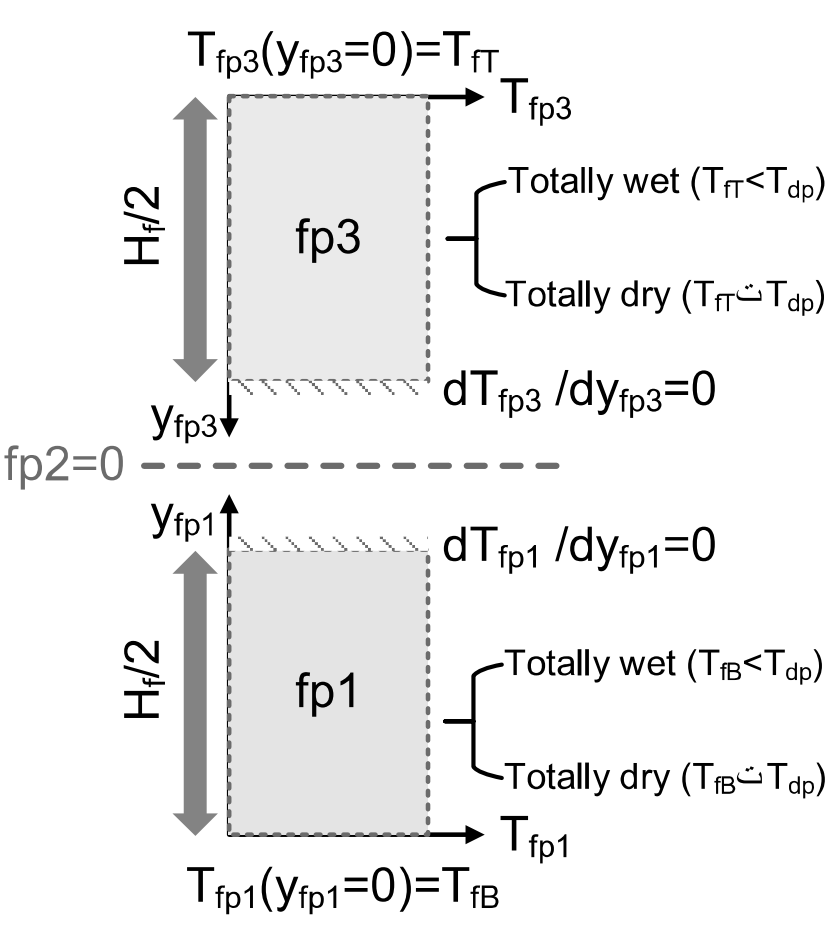

Fig. 14

Fig. 14 Fin discretization scheme used in MCHX-1D-CF model

Regarding the validation of R-134a evaporator, the results showed that the correlation of Mishima and Hibiki [48], for refrigerant-side frictional pressure drop coefficient, and correlation of Kandlikar and Balasubramanian [46], for refrigerant-side heat transfer coefficient, are the best combination regarding the heat transfer and pressure drop results. Based on this, the current model successfully estimated the inlet saturation temperature, refrigerant-side pressure drop, outlet air temperature, mass flow rate of condensed water, and cooling capacity with MAE values of $\pm 0.24{ }^{\circ} \mathrm{C}, \pm 9.12 \%, \pm 0.43{ }^{\circ} \mathrm{C}, \pm 5.4 \%$, and $\pm 1.8 \%$, respectively. It is worth mentioning that in the current validation study, the widely accepted correlations of Kim and Bullard $[12,13]$ were selected to estimate the air-side frictional pressure drop and heat transfer coefficients under dry and wet conditions.

Regarding the validation of $\mathrm{CO}_{2}$ evaporator, the results revealed that the most appropriate correlations for estimating the refrigerant-side frictional pressure drop and heat transfer coefficients, in this case, are the correlations of Tran et al. [11] and Kandlikar and Balasubramanian [46], respectively. Based on this, the proposed model predicted quite well the cooling capacity and outlet air temperature with MAE values of $\pm 4.3 \%$ and $\pm 0.9{ }^{\circ} \mathrm{C}$, respectively. Regarding the refrigerant-side pressure drop, the maximum deviation between the calculated and measured values was $11 \mathrm{kPa}$.

To study the effect of widely used assumption of cut fin at half the height (adiabatic-fin-tip assumption), a new model (MCHX-1D-CF) was developed. The comparison of air-side heat transfer rates between MCHX-1D-MB and MCHX-1D-CF models showed that the deviations in latent heat transfer rate were insignificant in the totally wet region. However, in the partially wet region, these deviations started to increase up to $\approx 12 \%$, with the decrease in the inlet air relative humidity. The assumption of cut fin, adopted by the MCHX-1D-CF model, prevents the heat conduction through the fin and underpredicts the fin temperature profile. This results to a misprediction of actual fin dehumidifying condition, making MCHX-1D-CF model always overpredicts the latent heat transfer rate compared to the MCHX-1D-MB model.
Fig. 15 Absolute relative deviations (ARD) in latent and sensible heat transfer rates between MCHX-1D-CF and MXHX-1D-MB models

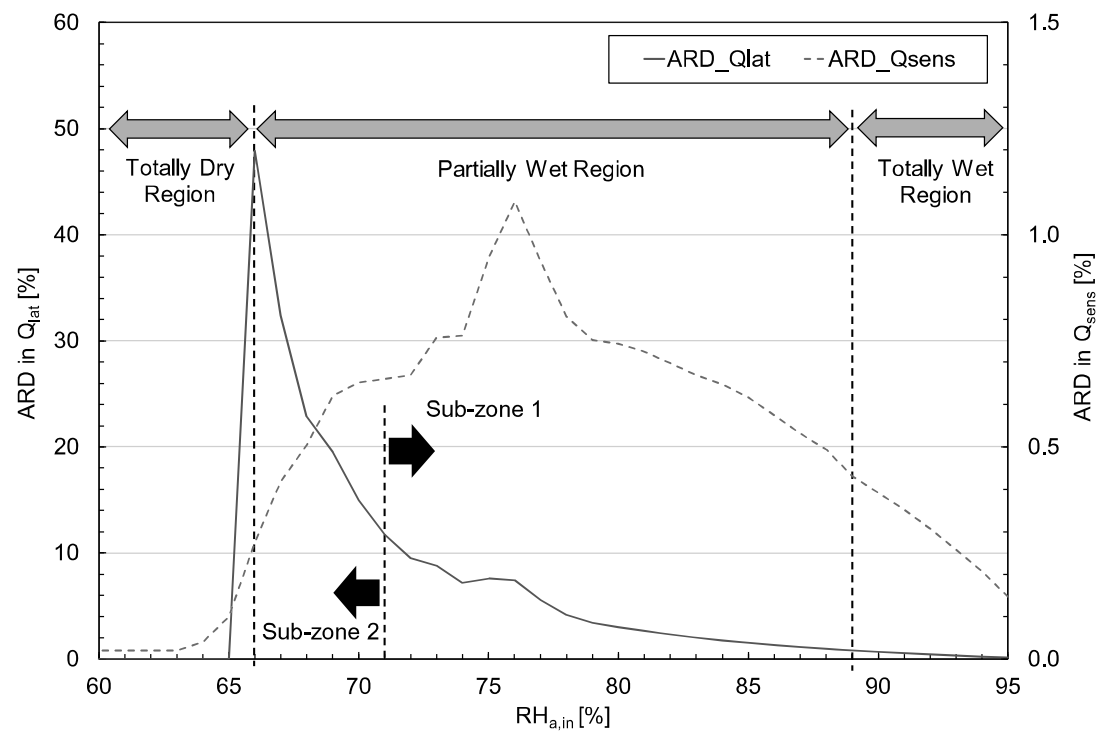



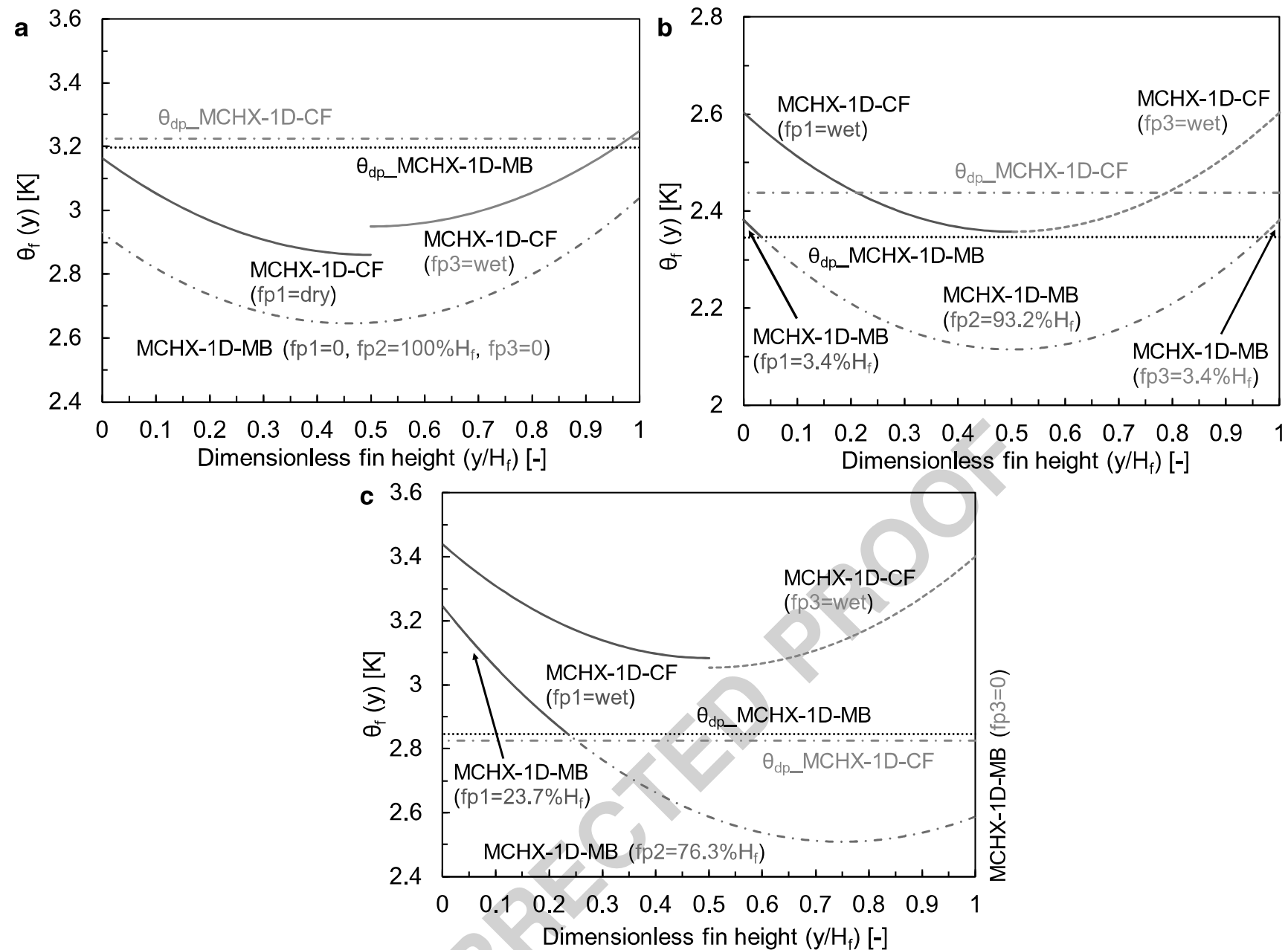

Fig. 16 Comparison of predicted fin temperature profiles between MCHX-1D-CF and MCHX-1D-MB models: $\mathbf{a}$ fin at 2 nd row, $\mathbf{b}$ fin at 5 th row, and $\mathbf{c}$ fin at 32th row

Acknowledgements The authors would like to gratefully acknowledge the financial support from the Spanish Ministry of Economy and Finance to project number ENE2014-53311-C2-1-P.

\section{Compliance with ethical standards}

Conflict of interest On behalf of all authors, the corresponding author states that there is no conflict of interest.

Publisher's note Springer Nature remains neutral with regard to jurisdictional claims in published maps and institutional affiliations.

\section{References}

1. Kim MH, Bullard CW (2001) Development of a microchannel evaporator model for a $\mathrm{CO} 2$ air-conditioning system. Energy 26: 931-948

2. Jin J, Chen J, Chen Z (2011) Development and validation of a microchannel evaporator model for a $\mathrm{CO} 2$ air-conditioning system. Appl Therm Eng 31:137-146. https://doi.org/10.1016/j. applthermaleng.2010.06.019
3. Wu XM, Webb RL (2002) Thermal and hydraulic analysis of a brazed aluminum evaporator. Appl Therm Eng 22:1369-1390. https://doi.org/10.1016/S1359-4311(02)00058-3

4. Brix W, Kærn MR, Elmegaard B (2009) Modelling refrigerant distribution in microchannel evaporators. Int J Refrig 32:1736-1743. https://doi.org/10.1016/j.ijrefrig.2009.05.006

5. Zhao Y, Liang Y, Sun Y, Chen J (2012) Development of a minichannel evaporator model using R1234yf as working fluid. Int J Refrig 35:2166-2178. https://doi.org/10.1016/j.jirefrig.2012.08. 026

6. Ren T, Ding G, Wang T, Hu H (2013) A general three-dimensional simulation approach for micro-channel heat exchanger based on graph theory. Appl Therm Eng 59:660-674. https://doi.org/10. 1016/j.applthermaleng.2013.06.035

7. Gossard JJ, Han X, Ramalingam M, Sommers AD (2013) Investigating the thermal-hydraulic performance of new refrigerant mixtures through numerical simulation of minichannel and microchannel evaporators. Appl Therm Eng 50:1291-1298. https://doi.org/10.1016/j.applthermaleng.2012.07.011

8. Huang L, Bacellar D, Aute V, Radermacher R (2015) Variable geometry microchannel heat exchanger modeling under dry, wet, and partially wet surface conditions accounting for tube-to-tube heat conduction. Sci Technol Built Environ 21:703-717. https:// doi.org/10.1080/23744731.2015.1047717 
1031

1032

1033

1034

1035

1036

1037

1038

1039

1040

1041

1042

1043

1044

1045

1046

1047

1048

1049

1050

1051

1052

1053

1054

1055

1056

1057

1058

1059

1060

1061

1062

1063

1064

1065

1066

1067

1068

1069

1070

1071

1072

1073

1074

1075

1076

1077

1078

1079

1080

1081

1082

1083

1084

1085

1086

1087

1088

1089

1090

1091

1092

1093

1094

1095

1096
9. Tian Z, Ma L, Gu B et al (2016) Numerical model of a parallel flow minichannel evaporator with new flow boiling heat transfer correlation. Int J Refrig 63:1-13. https://doi.org/10.1016/j.ijrefrig.2015. 10.032

10. Hwang Y (1997) Comprehensive investigation of carbon dioxide refrigeration cycle. PhD Thesis, University of Maryland, College Park

11. Tran TN, Chyu MC, Wambsganss MW, France DM (2000) Twophase pressure drop of refrigerants during flow boiling in small channels: an experimental investigation and correlation development. Int J Multiphase Flow 26:1739-1754. https://doi.org/10. 1016/S0301-9322(99)00119-6

12. Kim MH, Bullard CW (2002) Air-side thermal hydraulic performance of multi-louvered fin aluminum heat exchangers. Int J Refrig 25:390-400. https://doi.org/10.1016/S0140-7007(01)00025-1

13. Kim MH, Bullard CW (2002) Air-side performance of brazed aluminum heat exchangers under dehumidifying conditions. Int J Refrig 25:924-934. https://doi.org/10.1016/S0140-7007(01) 00106-2

14. Cheng L, Ribatski G, Wojtan L, Thome JR (2006) New flow boiling heat transfer model and flow pattern map for carbon dioxide evaporating inside horizontal tubes. Int J Heat Mass Transf 49: 4082-4094. https://doi.org/10.1016/j.ijheatmasstransfer.2006.04. 003

15. Jassim EW, Newell TA (2006) Prediction of two-phase pressure drop and void fraction in microchannels using probabilistic flow regime mapping. Int J Heat Mass Transf 49:2446-2457. https:// doi.org/10.1016/j.ijheatmasstransfer.2006.01.034

16. Petukhov BS, Kurganov VA, Gladuntsov AI (1973) Heat transfer in turbulent pipe flow of gases with variable properties. Heat Transf Sov Res 5:109-116

17. Shah MM (1976) A new correlation for heat transfer during boiling flow through pipes. ASHRAE Trans 82(Part 2):66-86

18. Zhang M, Webb RL (2001) Correlation of two-phase friction for refrigerants in small-diameter tubes. Exp Thermal Fluid Sci 25: 131-139. https://doi.org/10.1016/S0894-1777(01)00066-8

19. Webb RL, Hang YJ, Wang CC (1995) Heat transfer and friction correlation for louver fin geometry. In: 1995 vehicle thermal management system conference proceeding, pp 533-541

20. Zhang W, Hibiki T, Mishima K (2004) Correlation for flow boiling heat transfer in mini-channels. Int J Heat Mass Transf 47:57495763. https://doi.org/10.1016/j.jheatmasstransfer.2004.07.034

21. Müller-Steinhagen H, Heck K (1986) A simple friction pressure drop correlation for two-phase flow in pipes. Chem Eng Process Process Intensif 20:297-308. https://doi.org/10.1016/02552701(86)80008-3

22. Friedel L (1979) Improved friction pressure drop correlation for horizontal and vertical two-phase pipe flow. In: European twophase flow group meeting, Ispra, Italy

23. Chang Y-J, Wang C-C (1997) A generalized heat transfer correlation for Iouver fin geometry. Int J Heat Mass Transf 40:533-544. https://doi.org/10.1016/0017-9310(96)00116-0

24. Chang Y-J, Hsu K-C, Lin Y-T, Wang C-C (2000) A generalized friction correlation for louver fin geometry. Int J Heat Mass Transf 43:2237-2243. https://doi.org/10.1016/S0017-9310(99) 00289-6

25. Kandlikar SG, Steinke ME (2003) Predicting heat transfer during flow boiling in Minichannels and microchannels. ASHRAE Trans 109:1-9

26. Peters JVS, Kandlikar SG (2007) Further evaluation of a flow boiling correlation for microchannels and minichannels. In: 5th international conference on Nanochannels, microchannels and Minichannels (ICNMM2007), Puebla, Mexico

27. Field BS, Hrnjak P (2007) Adiabatic two-phase pressure drop of refrigerants in small channels. Heat Transf Eng 28:704-712. https:// doi.org/10.1080/01457630701326456
28. Park Y-G, Jacobi AM (2009) Air-side heat transfer and friction correlations for flat-tube louver-fin heat exchangers. J Heat Transf 131:021801. https://doi.org/10.1115/1.3000609

29. Park Y-G, Jacobi AM (2009) The air-side thermal-hydraulic performance of flat-tube heat exchangers with louvered, wavy, and plain fins under dry and wet conditions. J Heat Transf 131:061801. https://doi.org/10.1115/1.3089548

30. Deru M (2003) A model for ground-coupled heat and moisture transfer from buildings. Technical report. National Renewable Energy Laboratory, Golden

31. Tuo H, Hrnjak P (2012) Flash gas bypass in mobile air conditioning system with R134a. Int J Refrig 35:1869-1877. https://doi.org/10. 1016/j.ijrefrig.2012.05.013

32. Gungor KE, Winterton RHS (1986) A general correlation for flow boiling in tubes and annuli. Int J Heat Mass Transf 29:351-358. https://doi.org/10.1016/0017-9310(86)90205-X

33. Hu H t, Ding G 1, Huang X c et al (2009) Pressure drop during horizontal flow boiling of R410A/oil mixture in $5 \mathrm{~mm}$ and $3 \mathrm{~mm}$ smooth tubes. Appl Therm Eng 29:3353-3365. https://doi.org/10. 1016/j.applthermaleng.2009.05.011

34. McQuiston FC (1975) Fin efficiency with combined heat and mass transfer. ASHRAE Trans 81:350-355

35. Hassan AH, Martínez-Ballester S, Gonzálvez-Maciá J (2015) A comparative study between a two-dimensional numerical minichannel evaporator model and a classical effectiveness-NTU approach under different dehumidifying conditions. Sci Technol Built Environ 21:681-692. https://doi.org/10.1080/23744731. 2015.1028866

36. Hassan AH, Martínez-Ballester S, Gonzálvez-Maciá J (2016) Twodimensional numerical modeling for the air-side of minichannel evaporators accounting for partial dehumidification scenarios and tube-to-tube heat conduction. Int J Refrig 67:90-101. https://doi. org/10.1016/j.ijrefrig.2016.04.003

37. Hassan AH, Martínez-Ballester S, Gonzálvez-Maciá J (2017) A new moving boundary model for evaluating the performance of wet fins: application to minichannel evaporators. Appl Therm Eng 127:566-579. https://doi.org/10.1016/j.applthermaleng.2017. 08.055

38. IMST-ART (2010) Simulation tool to assist the selection, design and optimization of refrigeration equipment and components. In: Inst. Univ. Investig. en Ing. Energética. Univ. Politècnica València, Val http://www.imst-art.com/

39. Sharqawy MH, Zubair SM (2008) Efficiency and optimization of straight fins with combined heat and mass transfer - an analytical solution. Appl Therm Eng 28:2279-2288. https://doi.org/10.1016/j. applthermaleng.2008.01.003

40. Chisholm D (1972) An equation for velocity ratio in two-phase flow

41. Gnielinski V (1976) New equations for heat and mass transfer in turbulent pipe and channel flow. Int Chem Eng 16:359-368

42. Churchill SW (1977) Friction-factor equation spans all fluid flow regimes. Chem Eng 7:91-92

43. Kays WM, London AL (1984) Compact heat exchangers, 3rd edn. McGraw-Hill, New York

44. Bennett DL, Chen JC (1980) Forced convective boiling in vertical tubes for saturated pure components and binary mixtures. AICHE J 26:454 461. https://doi.org/10.1002/aic.690260317

45. Cooper MG (1984) Saturation nucleate pool boiling - a simple correlation. In: First U.K. National Conference on heat transfer, pp 785-793

46. Kandlikar SG, Balasubramanian P (2004) An extension of the flow boiling correlation to transition, laminar, and deep laminar flows in minichannels and microchannels. Heat Transf Eng 25:86-93. https://doi.org/10.1080/01457630490280425

47. Wojtan L, Ursenbacher T, Thome JR (2005) Investigation of flow boiling in horizontal tubes: part II - development of a new heat
1097

1098

1099

1100

1101

1102

1103

1104

1105

1106

1107

1108

1109

1110

1111

1112

1113

1114

1115

1116

1117

1118

1119

1120

1121

1122

1123

1124

1125

1126

1127

1128

1129

1130

1131

1132

1133

1134

1135

1136

1137

1138

1139

1140

1141

1142

1143

1144

1145

1146

1147

1148

1149

1150

1151

1152

1153

1154

1155

1156

1157

1158

1159

1160

1161

1162 
Heat Mass Transfer

1163

1164

1165

1166

1167

1168

1169

1170

1171

1172

1173

1174

1175

1176

1177

1193 transfer model for stratified-wavy, dryout and mist flow regimes. Int J Heat Mass Transf 48:2970-2985. https://doi.org/10.1016/j. ijheatmasstransfer.2004.12.013

48. Mishima K, Hibiki T (1996) Some characteristics of air-water twophase flow in small diameter vertical tubes. Int $\mathrm{J}$ Multiphase Flow 22:703-712. https://doi.org/10.1016/0301-9322(96)00010-9

49. Lee J, Mudawar I (2005) Two-phase flow in high-heat-flux microchannel heat sink for refrigeration cooling applications: part I pressure drop characteristics. Int J Heat Mass Transf 48:928-940. https://doi.org/10.1016/j.ijheatmasstransfer.2004.09.018

50. Corberán JM, De Córdoba PF, Gonzálvez J, Alias F (2001) Semiexplicit method for wall temperature linked equations (SEWTLE): a general finite-volume technique for the calculation of complex heat exchangers. Numer Heat Transf Part B Fundam 40:37-59. https://doi.org/10.1080/104077901300233596
51. Patankar SV (1980) Numerical heat transfer and fluid flow. Hemisphere Publishing Corporation, Washington

52. Coney JER, Sheppard CGW, El-Shafei EAM (1989) Fin perfor- 1180 mance with condensation from humid air: a numerical investiga- 1181 tion. Int J Heat Fluid Flow 10:224-231. https://doi.org/10.1016/ 1182 0142-727X(89)90041-6

53. Martínez-Ballester S, Corberán JM, Gonzálvez-Maciá J (2013) Numerical model for microchannel condensers and gas coolers: part II - simulation studies and model comparison. Int $\mathrm{J}$ Refrig 36:191-202. https://doi.org/10.1016/j.ijrefrig.2012.08.024

54. Beaver AC, Yin JM, Bullard CW, Hrnjak PS (1999) An experimental investigation of transcritical carbon dioxide systems for residential air conditioning. Report no. ACRC CR-18. Air Conditioning and Refrigeration Center, College of Engineering, University of Illinois at Urbana-Champaign 